Review

\title{
Current status of fuel cell based combined heat and power systems for residential sector
}

\author{
Harikishan R. Ellamla a, *, Iain Staffell ${ }^{\mathrm{b}}$, Piotr Bujlo a, Bruno G. Pollet a , \\ Sivakumar Pasupathi ${ }^{a}$ \\ ${ }^{a}$ Hydrogen South Africa (HySA) Systems and Validation Centre, SAIAMC, University of the Western Cape, Robert Sobukwe Road, Bellville, 7535, Cape Town, \\ South Africa \\ ${ }^{\mathrm{b}}$ Imperial College Business School, Imperial College London, London, SW7 2AZ, United Kingdom
}

\section{H I G H L I G H T S}

- Status of micro FC-CHP system activities in different countries is described.

- Technical potential of PEMFC and SOFC technology is presented.

- FC-CHP system main components are characterised and analysed.

- By doubling the production 25\% price reduction of micro FC-CHP system is possible.

- LT-PEMFC and SOFC is dominant but HT-PEMFC has potential for FC-CHP application.

\section{A R T I C L E I N F O}

\section{Article history:}

Received 26 January 2015

Received in revised form

6 May 2015

Accepted 14 May 2015

Available online 28 May 2015

\section{Keywords:}

Combined heat and power

Residential

Development status

Fuel cell

Efficiency

PEMFC

SOFC

\begin{abstract}
A B S T R A C T
Combined Heat and Power (CHP) is the sequential or simultaneous generation of multiple forms of useful energy, usually electrical and thermal, in a single and integrated system. Implementing CHP systems in the current energy sector may solve energy shortages, climate change and energy conservation issues. This review paper is divided into six sections: the first part defines and classifies the types of fuel cell used in CHP systems; the second part discusses the current status of fuel cell CHP (FC-CHP) around the world and highlights the benefits and drawbacks of CHP systems; the third part focuses on techniques for modelling CHP systems. The fourth section gives a thorough comparison and discussion of the two main fuel cell technologies used in FC-CHP (PEMFC and SOFC), characterising their technical performance and recent developments from the major manufacturers. The fifth section describes all the main components of FC-CHP systems and explains the issues connected with their practical application. The last part summarises the above, and reflects on micro FC-CHP system technology and its future prospects.
\end{abstract}

Crown Copyright $\odot 2015$ Published by Elsevier B.V. All rights reserved.

\section{Introduction}

Electric power and heat are the most important driving forces in energy in the modern world. World primary energy consumption is increasing with a growth rate of $1.8 \%$ and coal consumption is increasing at a rate of $2.5 \%$. In 2012 coal reached its highest share of global primary energy consumption since 1970 at $29.9 \%$. Meanwhile, global nuclear power output has decreased by $6.9 \%$, Japanese output has dropped by $89 \%$, accounting for $82 \%$ of the global decline

\footnotetext{
* Corresponding author.

E-mail address: hariehkr@gmail.com (H.R. Ellamla).
}

in 2012 [1]. Currently conventional coal-fired power plants are not able to meet present energy demands and reduce emissions; moreover the average efficiency of these plants is quite low at around $41 \%$. Almost $60 \%$ of the primary energy of the fuel used in these power plants becomes waste heat. Heat loss from power generation in the USA is equal to the total yearly energy use in Japan.

The world average split in residential energy consumption is about $27 \%$ electrical energy and 38\% thermal energy [2]. The division of residential energy consumption in different countries is shown in Fig. 1 [3]. Countries in colder climates, for example Germany or the UK, use more than $70 \%$ of their energy for space heating and $9 \%$ of their energy for water heating. On the contrary, 


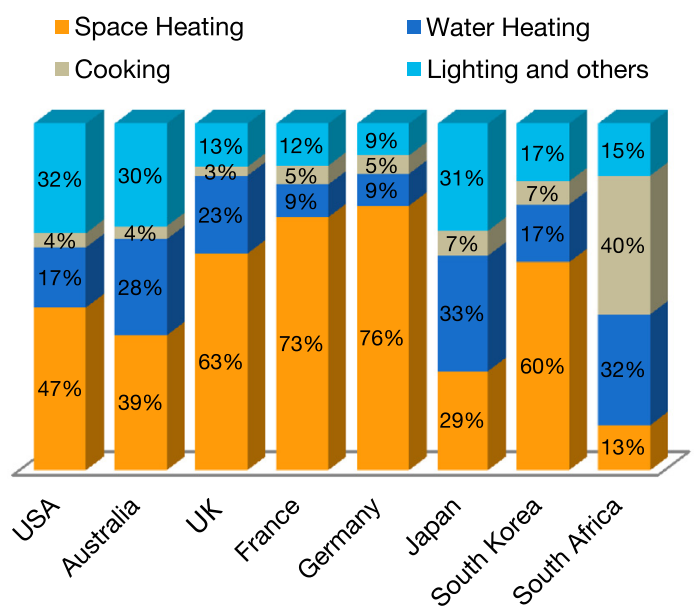

Fig. 1. Energy usage of typical household in different countries worldwide.

the Republic of South Africa uses only 13\% of its energy for space heating and $32 \%$ of its energy for hot water. Most of the countries do not use co-generated heat energy from power plants for other purposes such as space heating and water heating. Finland's residential energy consumption data published in 2012 shows that $29 \%$ of household energy consumption is from district heat and the remaining energy is from various sources, as shown in Fig. 2. Overall, almost $64 \%$ of total end-used electrical energy is used for space heating and the remaining $36 \%$ is an electrical energy supplied for household appliances [4].

In CHP technology, the waste heat is captured during operation and can be used for space heating, preparation of domestic hot water, laundry hot water as well as providing heat for swimming pools or spas. CHP reduces the amount of wasted energy by almost half and system can deliver energy with efficiencies exceeding $90 \%$, while significantly reducing emissions per produced kWh. CHP can be defined as the sequential or simultaneous generation of multiple forms of useful energy in a single integrated system. The total CHP system efficiency can be expressed as ratio of the sum of the net power and useful thermal energy output divided by the total energy of the consumed fuel. CHP systems can generate energy with efficiencies of up to 85-90\% (combined electrical and thermal efficiency), which is much higher in comparison with the efficiency of system that is generating electricity and useful heat in separate processes. This increased energy efficiency can result in a reduction of costs and a reduction in Green House Gas (GHG) emissions when compared to the conventional methods of generating heat and electricity separately.

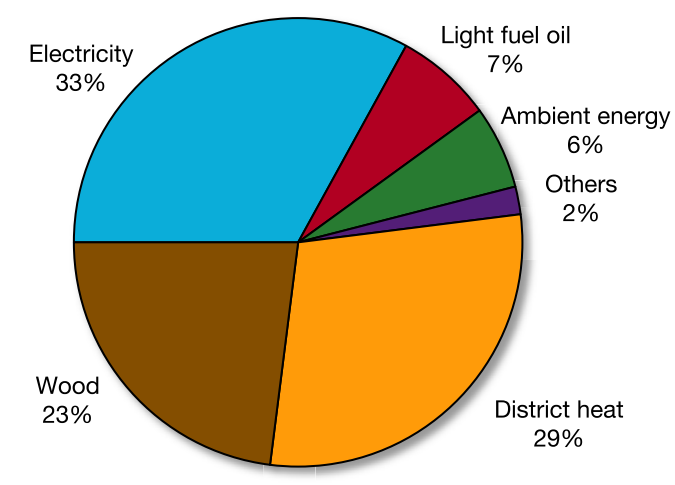

Fig. 2. Household energy consumption in Finland by energy source in 2012.
CHP technologies have higher system efficiency, higher fuel utilization efficiency, and lower emissions. They may also minimize power distribution losses because the production of energy can be decentralized. Many commercial office buildings and apartment complexes throughout the world are powered by CHP systems to save on energy costs, increase energy reliability and decrease carbon dioxide $\left(\mathrm{CO}_{2}\right)$ emissions (as well as other harmful gases) [5-7]. After the first oil crisis in 1973, many countries started to establish and/or promote an increased use of CHP systems. CHP systems gained attention in industrial/commercial as well as in institutional organizations mainly due to their high efficiencies, savings on energy bills and decreased GHG emissions [8]. The use of CHP in residential applications has increased as the systems have the ability to produce both thermal energy and electricity from a single source of fuel, yielding high overall efficiency [9]. CHP systems consist of several individual components configured into a fully integrated engineering system. The main components of the system, for instance the generator and heat recovery module, are shown in Fig. 3 (a basic system layout). The heat recovery subsystem captures the waste heat using a heat exchanger and the energy can then be utilized for heating purposes. The generator converts the chemical energy of the fuel into electrical energy. Cogeneration technologies for residential, commercial and institutional applications can be classified according to their prime mover and their energy source, as follows:

- Reciprocating Internal Combustion Engine (ICE) based cogeneration systems;

- Micro-turbine based cogeneration systems;

- Stirling engine based cogeneration systems; and

- Fuel cell based cogeneration systems.

The CHP technologies based on stirling engines and fuel cells seem to be promising for small scale cogeneration in residential buildings. The latter possess high overall efficiency and low emissions levels but currently ICEs are the only systems available offering reasonable costs. In addition, ICEs are attractive for small scale cogeneration CHP applications due to their robust nature and well-developed technologies. The other cogeneration technology that has potential for residential applications are microturbine based systems. However, reciprocating ICEs have higher efficiencies at lower power range and the capital cost of microturbines is higher compared to that of reciprocating ICE cogeneration systems [8]. A key constraint on the deployment of CHP is difficulty in distributing thermal energy over long distances. Because of this, CHP units must be located close to demand, which potentially increases the costs. The fuel cell based CHP systems have gained attention in recent decades, due to their higher achievable efficiencies over a broad range of load profiles and lower emissions without the need for additional controls.

\section{Fuel cell CHP systems}

A fuel cell is an electrochemical device which converts the chemical energy of a fuel and an oxidant, supplied continuously from external sources, into electrical energy in a direct process (without intermediate energy changes) with heat and water as byproducts and zero or very low harmful emissions. The fuel is typically either an alcohol, a hydrocarbon or a substance derived from it (e.g. hydrogen $\left(\mathrm{H}_{2}\right)$ ), which can be supplied continuously. The principle of operation is similar to that of batteries but instead giving energy continuously, as long as the fuel and oxidant are supplied. The fuel cell can produce electricity with no or with very little emissions; it operates quietly, without generating vibrations and the need for frequent disposal of the fuel cell when its fuel is 


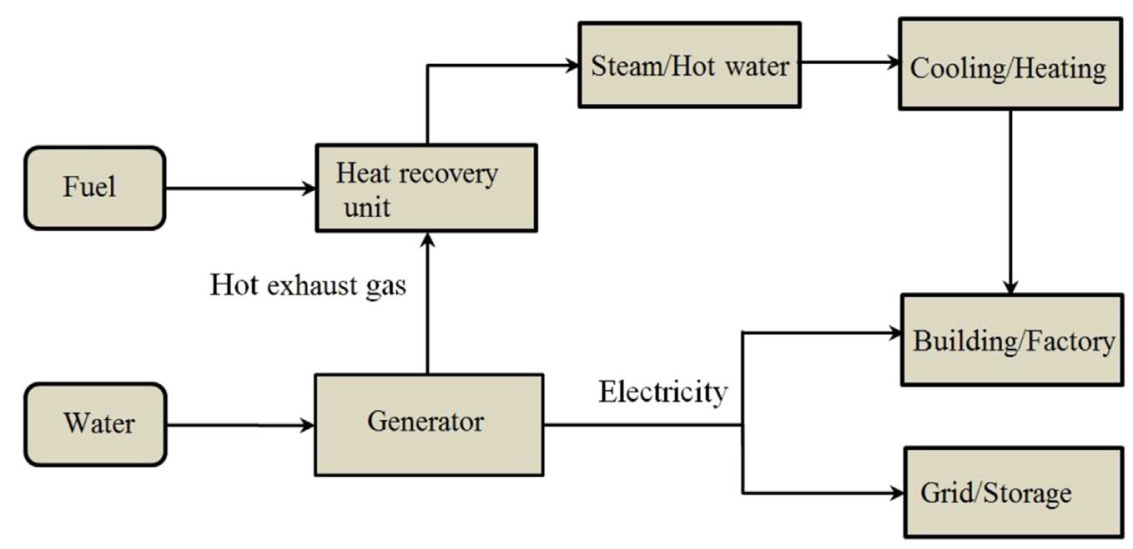

Fig. 3. CHP system components.

used up. Fuel cells can be potentially used in any applications that require electrical power ranging from a few hundreds of milli watts (mW) up to multi-kilowatt (kW) and megawatt (MW) sizes. They can be used in transport applications by replacing the ICEs or batteries as well as in portable applications for powering consumer devices such as laptops or cell phones. They can also be used in stationary power applications such as power generators to provide electricity for households or commercial buildings. The fuel cell also has the potential and capability to be used in cogeneration applications since the exothermic chemical and electrochemical reactions produce usable heat as by-product.

A Fuel Cell CHP (FC-CHP) system consists of three primary subsystems: (i) the fuel cell stack, (ii) the fuel processor and (iii) the power conditioning system. The fuel processor converts the fuel, for instance natural gas or methanol, into a hydrogen-rich feed stream that is supplied to the fuel cell stack which in turns generates electrical and thermal energy. The power conditioning system is used to convert the power generated by the stack as non-linear DC voltage into a form of electrical power which is useful for the enduser.

Fuel cells can be classified into different categories, based on a number of criteria, for example the combination of type of fuel and oxidant, whether the fuel is processed outside (external reforming) or inside (internal reforming) the fuel cell, the operating temperature and - the most commonly used classification - the type of electrolyte used. This classification includes Alkaline Fuel Cells (AFCs), Low Temperature Polymer Electrolyte Membrane Fuel Cells (LT-PEMFCs), High Temperature Polymer Electrolyte Membrane Fuel Cells (HT-PEMFCs), Phosphoric Acid Fuel Cells (PAFCs), Molten Carbonate Fuel Cells (MCFCs) and Solid Oxide Fuel Cells (SOFCs). While all fuel cell types are based on the same underlying electrochemical principles, they all operate at different temperature regimes, possess different materials and often differ in their performance characteristics. AFCs failed to reach commercialisation level due to durability and $\mathrm{CO}_{2}$ contamination issues [10]. This is the primary reason why this type of fuel cell is not used for domestic CHP systems. One may say it has been nearly neglected in the fuel cell community since interest in other fuel cell types began to increase [11], although some R\&D efforts are reported every now and then.

LT-PEMFCs show promising potential in the CHP market because of their low temperature operation and high efficiency. LT-PEMFCs operate at temperature of up to $80{ }^{\circ} \mathrm{C}$ and produce low-quality heat that is recovered in the form of hot water or/and low pressure steam ( 2 bar) that can be used for low temperature applications such as space/water heating in hospitals, universities or commercial buildings. The HT-PEMFCs have many advantages over LT technology, which will be discussed in more detail in Section 4 of this review paper. In general, the advantages spring from the increased operating temperature, which directly influences the requirements for stack design, system design and Balance of Plant (BoP) components that are used for construction. At temperatures above $100{ }^{\circ} \mathrm{C}$, no liquid water is present making water management within the stack much easier. It also simplifies bipolar plate flow field design and reduces reactants pressure drop along the fuel cell. The main advantages of moving to higher temperature stacks include: simplified and cheaper fuel processor construction as HT-PEMFC stack can tolerate up to 5 vol.\% of carbon monoxide (CO) with minor cell performance loss, simplification of the heat recovery system with no need for reactants humidification as phosphoric acid based membrane is used as electrolyte [12].

In PAFCs, concentrated phosphoric acid is used as the electrolyte and platinum is used as the electrocatalyst on both electrodes. PAFCs have been used for stationary power generators with a power output in the range of $100-400 \mathrm{~kW}$. PAFCs failed to reach commercialisation due to high cost and issues of corrosion of the fuel cell material.

In MCFCs, the electrolyte is made of a molten carbonate salt mixture which is suspended in a porous, chemically inert ceramic matrix of beta-alumina solid electrolyte. Non-precious metals are used as catalyst within the fuel cell electrodes (the anode and cathode). The high operating temperature of MCFCs and the corrosive nature of the electrolyte accelerate component breakdown and corrosion, decreasing lifetime. PAFCs and MCFCs are not suitable for domestic application but are widely used in large scale power plants.

SOFCs typically operate in the range $700-1000{ }^{\circ} \mathrm{C}$ and ceramic material is used in the Membrane Electrode Assembly (MEA) instead of metal oxides. Because of the very high operating temperatures, nickel can be used as a catalyst instead of using expensive precious metal catalysts. These fuel cells are in the precommercial stage for stationary power generation. Due to high operating temperatures they produce high-quality heat that is recovered in the form of steam (up to 10 bar) that can be used to supply energy for the internal reforming process used to produce $\mathrm{H}_{2}$.

FC-CHP systems achieve higher overall efficiencies than other available CHP technologies at small scale power range which is typical for domestic applications. FC-CHP can be used in the commercial/industrial sector which requires a high power range, typically between $200 \mathrm{~kW}$ and $2.8 \mathrm{MW}$ as well as in the residential and small commercial sectors which demand lower power ranges, typically $<10 \mathrm{~kW}$. The classification of FC-CHP systems based on 
their power range is presented in Table 1. On-site power generation is combined with the recovery of the by-product heat and its use. The quality of the heat depends upon the type of fuel cell used in the system, which has a direct influence on operating temperatures and the quality of heat that is recovered in the form of hot water or/ and low pressure steam.

The electrical efficiency of PAFC systems ranges from $37 \%$ to $42 \%$ and can reach $\sim 85 \%$ when operating in CHP mode [13]. The efficiency of the system can increase up to $90 \%$ when the system is able to take full advantage of the thermal output. MCFCs can achieve $\sim 47 \%$ electrical efficiency as a stand-alone power plant and can achieve $85 \%$ efficiency in CHP mode. The electrical efficiency target of $45 \%$ is likely to be achievable with HT-PEMFCs and SOFCs but unlikely to be achieved by LT-PEMFC. Only SOFC systems are likely to achieve the targeted CHP efficiency of $90 \%$ at the required electrical efficiency [14].

It can be seen from Table 1 and the discussion above that the most suitable and most commonly used FC technologies in the residential sector are PEMFC and SOFC. An estimated 138,000 FCCHP systems below $1 \mathrm{~kW}$ had been installed in Japan by the end of 2014 [15]. Most of these CHP systems are PEMFC based (85\%) and the remaining are SOFC systems. Currently, HT-PEMFC CHP systems are undergoing field trials and are expected to be launched by 2015. Fuel cell companies such as Elcore and PlugPower are working on the development and demonstration of HT-PEMFC CHP systems with an electrical power range of $300 \mathrm{~W}$ to $8000 \mathrm{~W}$. Fuel cells have been undergoing extensive development and demonstration for the past 50 years or so but the technology is still relatively immature for its complete commercialisation. FCCHP systems still have high installation costs in distributed generation and this is one of the few disadvantages for their market deployment.

\subsection{Current status of FC-CHP activities and systems development}

Fuel cells are slowly gaining global market share and have moved from laboratory to industrial showroom in the last decade. Commercially available micro $(\mu)$ FC-CHP systems available in the market are shown in Table 2 [16,17]. The market of domestic FC-
Table 2

Commercially available micro FC-CHP systems.

\begin{tabular}{llll}
\hline Manufacturer & Product name & FC type & Output power $(\mathrm{W})$ \\
\hline Ceramic fuel cells & BlueGen & SOFC & 1500 \\
Panasonic & ENE-FARM & LT-PEMFC & $250-750$ \\
Toshiba & ENE-FARM & LT-PEMFC & $250-700$ \\
EneosCellTech & ENE-FARM & LT-PEMFC & $250-700$ \\
Kyocera & ENE-FARM-S & SOFC & $250-700$ \\
Aisin Seiki & ENE-FARM-S & SOFC & $250-700$ \\
JxEneos & ENE-FARM-S & SOFC/HT-PEMFC & $250-700$ \\
\hline
\end{tabular}

CHP systems is growing rapidly but it is still behind other available domestic energy technologies [18]. As shown in Fig. 4, the number of FC-CHP systems in worldwide use has roughly doubled each year [19]. In 2013 it was reported that the fuel cell industry reached shipments of 45,700 units in 2012, totalling to $166.7 \mathrm{MW}$ of power capacity [20]. Delta-ee consultants stated in 2013 that with $64 \%$ of global market sales (approximately 28,000 units) $\mu \mathrm{FC}$ $\mathrm{CHP}$ passed conventional internal combustion engine systems in terms of sales. Japan leads in the global FC-CHP market, and is approximately $6-8$ years ahead of the markets in South Korea and Europe [21]. The Japanese government set a target of 1.4 million fuel cell systems installed by 2020; South Korea's target is 1 million and the European Union's target is 50,000 fuel cell systems installed by 2020 as shown by the dotted lines in Fig. 4 $[13,21]$.

FC-CHP systems are now being developed worldwide. In Europe, Germany is leading in the demonstration and development of domestic FC-CHP systems but other countries such as Denmark, the UK and the Netherlands are still conducting R\&D works on the technology. In Asia, Japan is the leader but South Korea is slowly but surely catching up with technology development. In North America, USA plays the largest, but still a small role, in domestic-scale CHP systems compared to industrial-scale CHP systems; this may be due to the unattractive financial and regulatory landscape. In Africa domestic FC-CHP technology has been under development for the past few years in South Africa (under the Hydrogen South Africa - HySA programme). The current status of FC-CHP systems in the various countries is discussed in more detail in the following

Table 1

FC-CHP systems classifications based on power range.

\begin{tabular}{|c|c|c|c|c|c|}
\hline Power range & MW class & Sub-MW class & & Micro CHP & \\
\hline FC type & MCFC & PAFC & SOFC & PEMFC & SOFC \\
\hline Electrical capacity & $300 \mathrm{~kW}-2.8 \mathrm{MW}$ & $400 \mathrm{~kW}$ & up to $200 \mathrm{~kW}$ & $<10 \mathrm{~kW}$ & \\
\hline $\begin{array}{l}\text { Operating temperature } \\
\quad\left({ }^{\circ} \mathrm{C}\right)\end{array}$ & $600-700$ & $160-220$ & $700-1000$ & $\begin{array}{l}60-80^{\mathrm{a}} \\
100-200^{\mathrm{b}}\end{array}$ & $700-1000$ \\
\hline Electrolyte & $\begin{array}{l}\mathrm{Li}_{2} \mathrm{CO}_{3} / \mathrm{K}_{2} \mathrm{CO}_{3} \text { materials } \\
\text { stabilized in an alumina } \\
\text { based matrix }\end{array}$ & $\begin{array}{l}100 \% \text { phosphoric acid } \\
\text { stabilized in an SiC based } \\
\text { matrix }\end{array}$ & $\begin{array}{l}\mathrm{ZrO}_{2} \text { supported ceramic } \\
\text { electrolytes }\end{array}$ & $\begin{array}{l}\text { Polymer membrane } \\
\text { Nafion }^{(B a} \\
\text { PBI }^{\text {b }}\end{array}$ & $\begin{array}{l}\mathrm{ZrO}_{2} \text { supported } \\
\text { ceramic electrolytes }\end{array}$ \\
\hline Typical application & $\begin{array}{l}\text { Utilities, large universities, } \\
\text { industrial-baseload }\end{array}$ & $\begin{array}{l}\text { Commercial } \\
\text { buildings-baseload }\end{array}$ & $\begin{array}{l}\text { Commercial } \\
\text { buildings-baseload }\end{array}$ & \multicolumn{2}{|c|}{ Residential and small commercial } \\
\hline Fuel source & Natural gas, biogas, others & Natural gas & Natural gas & Natural gas & \\
\hline Fuel compatibility & $\mathrm{H}_{2}, \mathrm{CH}_{4}$ (internal reformer) & $\mathrm{H}_{2}$ (external reformer) & $\begin{array}{l}\mathrm{H}_{2}, \mathrm{CH}_{4}, \mathrm{CO} \\
\text { (internal reformer) }\end{array}$ & $\begin{array}{l}\mathrm{H}_{2} \text {, methanol or ethanol } \\
\text { (external reformer) }\end{array}$ & $\begin{array}{l}\mathrm{H}_{2}, \mathrm{CH}_{4}, \mathrm{CO} \\
\text { (internal reformer) }\end{array}$ \\
\hline Oxidant & $\mathrm{O}_{2} / \mathrm{CO}_{2} /$ air & $\mathrm{O}_{2} /$ air & $\mathrm{O}_{2} /$ air & $\mathrm{O}_{2} /$ air & \\
\hline Advantages & $\begin{array}{l}\text { High efficiency, scalable, } \\
\text { fuel flexible }\end{array}$ & $\begin{array}{l}\text { High cogeneration } \\
\text { efficiency }\end{array}$ & High efficiency & System availability > 97\% & \\
\hline Electrical efficiency & $43-47 \%$ & $40-42 \%$ & $50-60 \%$ & $25-35 \%$ & $45-55 \%$ \\
\hline CHP efficiency & $85 \%$ & $85-90 \%$ & $90 \%$ & $\begin{array}{l}87-90 \%{ }^{\mathrm{a}} \\
85-90 \%\end{array}$ & $90 \%$ \\
\hline CHP applications & $\begin{array}{l}\text { Steam, hot water, chilling } \\
\text { and bottoming cycles }\end{array}$ & Hot water, chilling & $\begin{array}{l}\text { Depends on technology } \\
\text { used }\end{array}$ & Suitable for facility heating & \\
\hline $\begin{array}{l}\text { Primary contamination } \\
\text { sensitivities }\end{array}$ & Sulphur & $\mathrm{CO}<1 \%$, and sulphur & Sulphur & $\begin{array}{l}\mathrm{CO}<10 \mathrm{ppm}^{\mathrm{a}} \text {, } \\
\mathrm{CO}<5 \% \text {, sulphur and } \mathrm{NH}_{3}\end{array}$ & Sulphur \\
\hline
\end{tabular}

a LT-PEMFC.

b HT-PEMFC. 


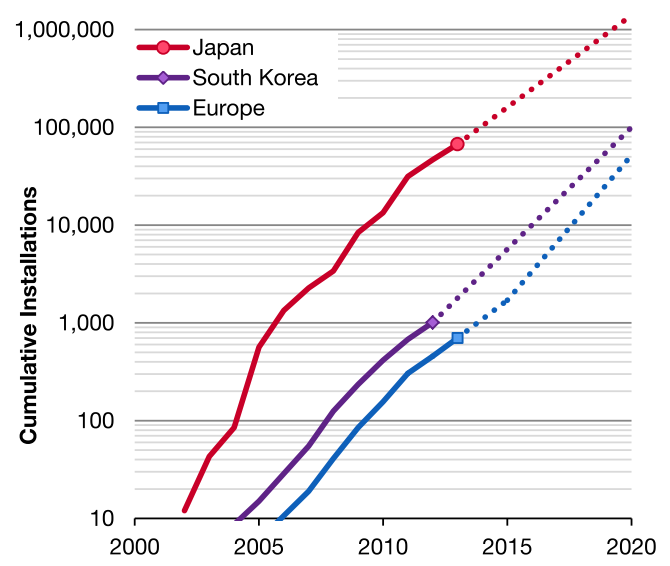

Fig. 4. Cumulative number of residential micro CHP systems installed to date (solid lines) and near-term projections (dotted lines). Both PEMFC and SOFC are included (with approximately 90:10 split), and Europe is almost entirely driven by German installations [19].

sections.

\subsubsection{Europe}

Europe has a share of $11 \%$ of installed CHP capacity in the cogenerated electricity business. The Ene-field programme (echoing the Japanese programme Ene-Farm) is a European-wide $\mu$-CHP field demonstration scheme that was launched in 2013 and its aim is to install around 1000 fuel cell $\mu$-CHP systems across 12 Member States of the European Union by 2017 with an expected cost of $\sim$ US\$69.5 million [22].

2.1.1.1. Germany. In Germany, CHP represented almost $12.6 \%$ of the total electricity generated, with an installed capacity of $21 \mathrm{GW}$ in 2005. Germany's new CHP laws are expected to double electricity generation by 2020 [23]. Germany is well-positioned in both biogas CHP and $\mu$-CHP for smaller-scale commercial and residential installations. Germany is in second place in the installation of FC-CHP systems, where 350 systems have been installed between September 2008 and the end of 2012 under the National Organisation Hydrogen and Fuel Cell Technology's light house project CALLUX [20,24]. The project aims to install 72,000 units by 2020 with a target cost of $€ 1700 \mathrm{~kW}^{-1}$ (US\$2040 $\mathrm{kW}^{-1}$ ). Panasonic and Viessmann have set up a joint development agreement in the $\mathrm{Eu}-$ ropean market, and have jointly designed the complete FC-CHP system. The fuel cell was designed by Panasonic and will be built in Japan before being sent to Germany for integration by Viessmann. The system generates $750 \mathrm{~W}$ of electricity and $1 \mathrm{~kW}$ of thermal energy with a combined efficiency of $90 \%$ [25]. The sale of systems currently under field testing is expected to start in Germany by 2014.

2.1.1.2. Denmark. Danish $\mu$-CHP opened a cooperation that consists of 9 Danish companies that are actively working on the development and demonstration of micro FC-CHP technology. The first phase of development in the project started in 2006 [26]. The demonstration projects have started on hydrogen fuel based LTPEMFCs, natural gas based HT-PEMFC and SOFC based technology. The first domestic FC-CHP installation was launched in late 2008 and the last phase of the project with 30 demonstration units will end in 2014 [27]. Currently, Denmark's single-family houses use approximately 400,000 heating units from oil based technology and their installations are being halted. In the 'Energy Strategy 2050' document, the Danish government announced that the installation of polluting boilers in households will be halted as of
2017. The same document assumes that by this time FC based CHP systems will be developed to a stage when they are able to deliver electricity at competitive prices. According to the Danish fuel cell industry, the domestic market for, produced by IRD Fuel Cell, CHP systems has the potential to reach 10,000 units annually generating a revenue of approximately $€ 60$ (US\$72) million.

2.1.1.3. UK. Taking advantage of favourable feed-in tariff rates in the UK, the Australian owned company Ceramic Fuel Cells Limited (CFCL) launched a scheme in 2013, offering fully financed BlueGen units for social housing, schools and small businesses. Customers are able to reduce their electricity costs by signing a 10 -year contract (feed-in tariff), after which they gain ownership of the system. Financiers are expecting about 6-9\% return on capital investment over the 10-year period [28]. Unfortunately in March 2015, CFCL announced that they were entering administration.

2.1.1.4. Netherlands. The Netherlands $\mu$-CHP subsidy ended in 2012 which led the $\mu$-CHP market in the country to near collapse [29]. Ceres Power and Itho-Daalderop jointly developed a low cost CHP product and aim to sell FC-CHP products in the residential commercial market in the Benelux countries (Belgium, Netherlands and Luxembourg). The Ceres Power and Itho-Daalderop FC-CHP product is now in a trial phase of testing (to be launched in 2016) [17]. More details of $\mu-\mathrm{FC}-\mathrm{CHP}$ system undergoing field trials are shown in Table 3 [30].

\subsubsection{Japan}

Japan can be considered at the forefront in CHP installations and commercialization. The project on CHP research development and demonstration (RD\&D) in Japan was launched by the government in the 1990's with the development of a $1 \mathrm{~kW}_{\mathrm{el}}$ PEMFC CHP system based on gas-derived hydrogen to produce heat and power for residential homes. These CHP systems are integrated with fuel processors that can be supplied with natural gas, Liquid Petroleum Gas (LPG) or kerosene, additionally the unit can deliver hot water up to a maximum temperature of $60{ }^{\circ} \mathrm{C}$. By 2005 successful installations of $50 \mathrm{CHP}$ units in private homes were carried out and afterwards a large-scale demonstration project was started throughout the country. In the first stage of the project around $3357 \mu \mathrm{FC}-\mathrm{CHP}$ units were installed by the end of 2008 and then the commercialization phase began in 2009 [31]. In 2011, the Tōhoku earthquake resulted in critical electricity supply shortages as nuclear and thermal power plants were heavily damaged), which convinced government to sustain subsidies for gas fuelled $\mu \mathrm{CHP}$ systems. A national subsidy of more than US\$4 billion was reported in 2012 for all hydrogen and fuel cell related $R \& D$ in Japan. With help of the government subsidies, more than 25,000 units were installed by the end of 2012 , and recent estimates show annual sales of 53,000 CHP units with accumulated sales of 138,000 units by the end of 2014 [15]. The Japanese government has a long term goal of 5.3 million fuel cell installations by 2030 $[16,22]$.

The total, industrial and commercial, CHP system capacity reached $9.5 \mathrm{GW}$ in 2011 and a targeted capacity of $22 \mathrm{GW}$ is predicted by 2030 . In order to meet $15 \%$ of the domestic electricity demand using CHP by 2030, an investment of approximately US\$60 billion is required. Major companies like Panasonic, Eneos (JX Nippon Oil \& Sanyo), Aisin Seiki Co. Ltd and Toshiba successfully commercialized PEMFC CHP systems (under the common commercial name of "ENE-FARM") with an electrical power output of $700 \mathrm{~W}_{\mathrm{el}}$ (see Table 4 for more details). A project on a SOFC based CHP system named "ENE-FARM type S" was led by JX Nippon Oil and Energy in 2011 and by Aisin in 2012. Companies like Kyocera and Eneos also started installations of SOFC 
Table 3

Micro FC-CHP systems under field trials.

\begin{tabular}{|c|c|c|c|}
\hline Manufacturer & FC type & Output power $(\mathrm{W})$ & Remarks \\
\hline Dantherm Power & LT-PEMFC & $1700-2500$ & Under field trials in Denmark, 2013 \\
\hline Baxilnnotech & LT-PEMFC & 300 & Under field trials in Germany, UK and market launch planned for 2015 \\
\hline Elcore & HT-PEMFC & 750 & First field trial installation was done 2013 \\
\hline Viessmann & LT-PEMFC & $250-700$ & Ready to launch in Germany by April 2014 \\
\hline Vaillant & LT-PEMFC & $1000-4600$ & Developing for multi-family home \\
\hline Sofc power & SOFC & $500-1000$ & Prototype packaged micro CHP system \\
\hline Hexis & SOFC & 1000 & Field trials in Germany, Switzerland under Callux project \\
\hline Ceres power & SOFC & 1000 & Ready to launch by 2016 \\
\hline Vaillant & SOFC & 1000 & Under field trials in Germany, 2013 \\
\hline Topsoe & SOFC & 1000 & Prototype packaged micro CHP system of larger (20 kWe) product \\
\hline Acumentrics & SOFC & $250-1500$ & A wall-mounted residential CHP unit is in field trials \\
\hline Hyosung, GS Fuelcell, fuel cell power & LT-PEMFC & 1000 & RPGs (Residential power generators) are in field trials \\
\hline Plug power & HT-PEMFC & $300-8000$ & Under field trials in Europe in the product name of GenSys \\
\hline
\end{tabular}

based CHP and approximately 300 units were pre-ordered by March 2012.

\subsubsection{South Korea}

The South Korean government identified fuel cells as a priority technology and a budget of US\$11.8 billion was allocated for the development of the technology in the period of 2003-2012. In 2004, the first Residential Power Generators (RPGs) with a capacity of $1 \mathrm{~kW}_{\mathrm{el}}$ completed an initial field test phase. After the successful initial field test of RPGs in 2004, 4 South Korean companies (GS Fuel Cell, FuelCell Power, HyoSung and $L S$ ) began demonstrating the fuel cell in field trials and installed 210 units between 2006 and 2009, at a cost of US\$18 million in subsidies [18]. The government hopes to reduce the technology gap with other countries through the development of fuel cell systems and expects to achieve commercial sales by 2015 . The government is subsidising $80 \%$ of the purchase price of the $\mu \mathrm{FC}-\mathrm{CHP}$, plus up to $10 \%$ additional subsidy is available from local governments [32].

\subsubsection{USA}

As of 2012, commercial buildings and institutional applicants represented $13 \%$ of CHP systems in the USA. Currently, the USA has reached an installed capacity of over $82 \mathrm{GW}$ of CHPs equating to $8 \%$ of the country's current generating capacity and over $12 \%$ of the total MWh generated annually [14]. While $87 \%$ of the existing USA $\mathrm{CHP}$ capacity is at industrial facilities, $\mathrm{CHP}$ can also be an attractive resource for commercial or institutional facilities such as schools and hospitals, in district energy systems, as well as in military installations. ClearEdge Power has sold $5 \mathrm{~kW}$ residential-scale FC-CHP systems, primarily in the California market where state subsidies help to offset the cost of the system [22].

\subsubsection{South Africa}

In 2008 the South African government launched a long-term (15-year) initiative with the aim of developing hydrogen and fuel cell technologies with an estimated budget of about US\$7-8 million per year [33]. The Hydrogen South Africa ${ }^{\mathrm{TM}}$ (HySA ${ }^{\mathrm{TM}}$ ) programme focuses, among other things, on the development of hydrogen and fuel cell components, systems, demonstrators, prototypes and products. The project realized as part of the Key Programme Combined Heat and Power aims to develop 1-2 $\mathrm{kW}_{\mathrm{el}}$ scale HT-PEMFC based FC-CHP system [34]. The testing and validation of the first South African prototype is planned for 2015 (Q2) and a trial in the residential sector will follow (Q3).

\subsubsection{Australia}

In 2009, the company CFCL launched its first FC-CHP product for residential applications: the $1.5 \mathrm{~kW}_{\mathrm{el}}$ "BlueGen", a planar type SOFC based FC-CHP system fed with natural gas. Since 2010 several units have been tested worldwide, with proven electrical efficiencies of up to $60 \%$ and a maximum total efficiency of $85 \%$. After the successful installation of CHPs in Australia, the company had driven towards rapid expansion in major markets for natural-gas fed $\mu \mathrm{CHP}$ in the USA, China, India and Brazil [35,36]. By 2015, CFCL had installed 50 BlueGen units in the UK, 100 units in Germany around 400 in other countries worldwide [37]. CFCL expected that 100,000 units would be delivered in the next 6 years as part of the postdemonstration agreement; however the company entered administration in March 2015.

\subsection{FC-CHP advantages}

\subsubsection{Reduction of $\mathrm{CO}_{2}$ emissions}

Global energy-related $\mathrm{CO}_{2}$ emissions stood at $31.2 \mathrm{Gt}$ in 2011, an increase of $3.2 \%$ on the previous year, which is above the average

Table 4

FC-CHP systems in Japan.

\begin{tabular}{|c|c|c|c|c|}
\hline & Viessmann and Panasonic & EneosCellTech & Toshiba & Kyocera \\
\hline Fuel & LPG/city gas & LPG/city gas & LPG/LNG/NG & LPG/city gas \\
\hline Fuel cell type & PEMFC & SOFC & PEMFC & SOFC \\
\hline Power output (W) & 750 & 700 & 700 & 700 \\
\hline General efficiency (LHV, \%) & 37 & 45 & 38.5 & 46.5 \\
\hline Thermal efficiency (LHV, \%) & 56 & 42 & 55.5 & 43.5 \\
\hline Dimensions $\mathrm{H} \times \mathrm{W} \times \mathrm{D}(\mathrm{mm})$ & $1670 \times 480 \times 475$ & $900 \times 302 \times 563$ & $1000 \times 780 \times 300$ & $935 \times 600 \times 335$ \\
\hline Weight (kg) & 125 & 92 & 94 & 94 \\
\hline Noise level (dB) & 38 & 38 & $37-48$ & 38 \\
\hline Water storage unit $\mathrm{H} \times \mathrm{W} \times \mathrm{D}(\mathrm{mm})$ & $1950 \times 600 \times 600$ & $1760 \times 310 \times 740$ & $1760 \times 750 \times 440$ & $1760 \times 740 \times 310$ \\
\hline Tank capacity (litre) & 170 & 90 & 200 & 90 \\
\hline $\begin{array}{l}\text { Suggested retail price (including consumption tax, } \\
\text { by construction cost) }\end{array}$ & $\begin{array}{l}¥ 1,995,000 \text { (US\$22,166) } \\
2013\end{array}$ & $\begin{array}{l}¥ 2,700,000 \text { (US\$33,750) } \\
2012\end{array}$ & $¥ 2,604,000$ (US\$32,550) & $¥ 2,751,000$ (US\$34,387) \\
\hline
\end{tabular}


growth rate of $2.5 \%$ in the last ten years [38]. This sector's emissions are expected to continue rising to $37 \mathrm{Gt}$ in 2035, which is estimated to drive global temperatures to rise by $3.6^{\circ} \mathrm{C}$ by 2035 relative to the pre-industrial era, well above the widely-held target of $2{ }^{\circ} \mathrm{C}$. A significant portion of the GHG emission growth is due to the increased coal demand: coal accounted for a total of $71 \%$ of additional global $\mathrm{CO}_{2}$ emissions, followed by oil at $17 \%$ and natural gas at $12 \%$.

The development and expansion of CHP systems can reduce the $\mathrm{CO}_{2}$ emissions arising from new generation in 2015 by more than 4\% (170 Mt/year), while in 2030 this saving may increase to more than $10 \%$ (950 Mt/year) which is equivalent to one and a half times India's total annual emissions of $\mathrm{CO}_{2}$ from power generation [38]. $\mathrm{CHP}$ can therefore make a meaningful contribution towards the achievement of emissions stabilisation that is necessary to avoid major climate disruption. Importantly, near-term emissions reductions from $\mathrm{CHP}$ can be realised immediately offering important opportunities for low- and zero-cost GHG emission reductions. Fuel cells can reduce carbon emissions relative to conventional heating technologies like gas boilers as they reduce the amount of electricity that needs to be generated centrally and distributed via the grid, which in most countries has high carbon intensity.

Annual $\mathrm{CO}_{2}$ savings are difficult to estimate as they are country specific, depending upon the carbon intensity of central grid electricity and local heating systems; and installation specific, depending on the level of demand for heat and power. Residentialscale FC-CHP systems of around $1 \mathrm{~kW}$ are expected to reduce household emissions by $1.3-1.9$ tons of $\mathrm{CO}_{2}$ per annum in Japan and Germany [38], [39]. The FC-CHP manufacturer CFCL claims that its BlueGen saves around 3 tonnes per annum due to its larger capacity [40]. A $\mu$ FC-CHP system with an electrical output of $1 \mathrm{~kW}$ can yield a daily saving of $4.5+\mathrm{kg} \mathrm{CO}$ in winter and $3+\mathrm{kg} \mathrm{CO}$ in summer. Annual carbon emissions have been estimated based on PEMFC operation in a UK house and results compared with conventional heating systems are shown in Fig. 5 [41]. In a country which uses predominantly coal-fired electricity generation (such as South Africa or China), the annual carbon savings from a fuel cell will be much larger.

In general, the carbon intensity of electricity from a $\mu \mathrm{FC}-\mathrm{CHP}$ system is only one third that of a coal-fired plant and half that of a natural gas plant [42]. For example, UK central electricity generation has an average carbon intensity of $500-520 \mathrm{~g} \mathrm{kWh}^{-1}$, while the marginal plants (those which vary their output with demand) may have a carbon intensity of up to $690 \mathrm{~g} \mathrm{kWh}^{-1}[43,44]$
In comparison, a residential PEMFC system emits around $553 \mathrm{~g}$ of $\mathrm{CO}_{2}$ to produce $1 \mathrm{kWh}$ of electricity and $1.4 \mathrm{kWh}$ of heat (assuming the typical efficiency for Ene-farm systems as in Fig. 5) [45]. The source of these $\mathrm{CO}_{2}$ emissions is the fuel processor, which separates a hydrocarbon fuel (typically natural gas or LPG) into $\mathrm{H}_{2}$, $\mathrm{CO}_{2}$ and other impurities, burning a small amount of fuel in the process to produce heat for the reforming reactions. See Sections 4.1.2 And 5.2 later on for more detail.

It is difficult to place a single carbon intensity value to a $\mathrm{CHP}$ system with multiple outputs. The carbon intensity of electricity from an FC-CHP system can be estimated using the usual method by avoiding heat production from a gas boiler and by taking into account the total electricity produced from the fuel cell. From the above example, this would yield $553-(1.4 \times 215)=252 \mathrm{~g} \mathrm{kWh}^{-1}$ of electricity produced, around $40 \%$ lower than the best Combined Cycle Gas Turbine (CCGT) plants. This calculated value for an Enefarm-type system is similar to those commonly used to promote larger FC-CHP power plant installations, e.g. $225 \mathrm{~g} \mathrm{kWh}^{-1}$ of electricity from PAFC [46], and 238-308 $\mathrm{g} \mathrm{kWh}^{-1}$ from MCFC [47]. The carbon intensity of the conventional heating and electricity generating technologies which are replaced by an FC-CHP system has significant impacts on the annual $\mathrm{CO}_{2}$ savings, as seen in Fig. 5.

The carbon intensity can be calculated for the amount of heat produced instead of the electrical output [45]. Using the above example and assuming that the electricity from the FC-CHP system reduces output from central power stations, $1.4 \mathrm{kWh}$ of heat (results in the emission of 553-510 (the average carbon intensity of a UK central power plant) $=43 \mathrm{~g} \mathrm{CO}_{2}$, which divided by $1.4 \mathrm{kWh}$ gives a carbon intensity of just $30 \mathrm{~g} \mathrm{kWh}^{-1}$. This is a seven-fold reduction on the carbon intensity of heat from a modern condensing gas boiler. If similar calculations are repeated with more efficient SOFC stacks, the heat output leads to carbon negative values $\left(-49 \mathrm{~g} \mathrm{kWh}^{-1}\right)$ when displacing power from a UK central power plants. From the above, one may state that the gas-fired technology can offer a zero carbon heat. Combining all the multiple uses of a fuel cell (electricity, space heating and hot water) and the broad applicability in the residential buildings sector, fuel cells could be considered as a core part of the world's decarbonisation strategy.

\subsubsection{Carbon footprint of construction}

The 'carbon footprint' or 'embodied carbon' of a fuel cell is a measure of the GHG emissions caused by its construction. Several life cycle assessments have estimated these carbon emissions by considering how the fuel cell is manufactured, the quantity of
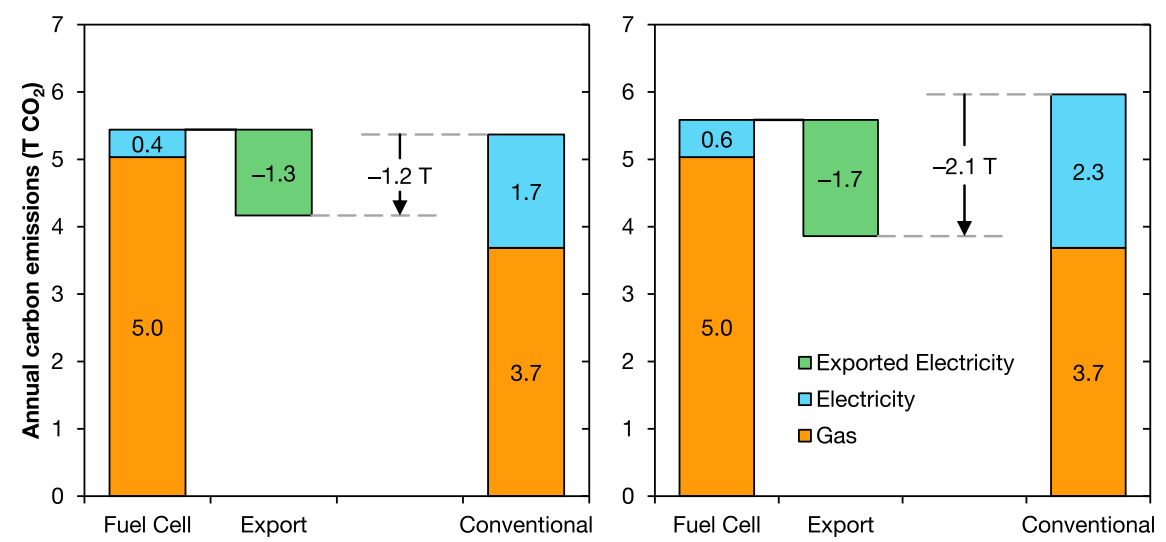

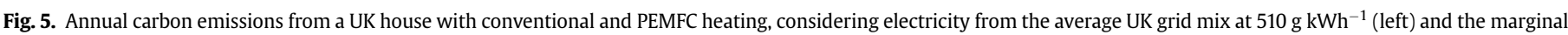

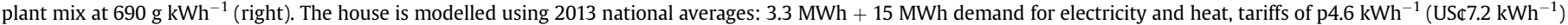

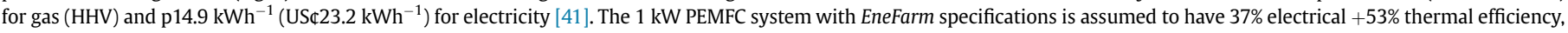
running $5000 \mathrm{~h}$ per year, versus a condensing boiler with $95 \%$ efficiency. 
materials required and how these materials are produced. In the fuel cell, catalyst metals such as nickel and platinum (Pt) are exceedingly energy intensive to produce. Manufacturing a $1 \mathrm{~kW}$ residential FC-CHP system results in around 0.5-1 tonnes of $\mathrm{CO}_{2}$ emissions, while a $100 \mathrm{~kW}$ commercial system results in 25-100 tonnes emitted $[48,49]$. There are differences between technologies, but these are small compared to the differences between the country of manufacture and type of production methods employed by various manufacturing companies.

The emissions from construction can be 'levelised' by averaging over the fuel cell's lifetime energy output to give a value which can be compared to other low carbon technologies. The construction of residential PEMFCs and SOFCs results in the emission of 10-20 g of $\mathrm{CO}_{2}$ per kWh of electricity produced [48], which is relatively low compared to solar photovoltaic (PV) which has a life-cycle carbon intensity of $40-80 \mathrm{~g} \mathrm{kWh}^{-1}$, and nuclear fission having a carbon intensity of $10-30 \mathrm{~g} \mathrm{kWh}^{-1}[50,51]$.

\subsubsection{Reduction of other air pollutant emissions}

The process of burning fossil fuels (mainly diesel and coal) results in emissions of several air pollutants like nitrogen oxides $\left(\mathrm{NO}_{\mathrm{x}}\right)$ and sulphur dioxide $\left(\mathrm{SO}_{2}\right)$. The largest source of $\mathrm{SO}_{2}$ emissions is from the electricity generation, which accounts for $44 \%$ of the total emissions recorded in 2011 [52]. SO $\mathrm{SO}_{2}$ emissions are mainly related to the burning of coal and also diesel fuel, while $\mathrm{NO}_{\mathrm{x}}$ pollutants are emitted from burning all types of fossil fuels. The emissions cause a number of environmental problems such as acid rain, air pollution and ground-level ozone formation.

During the primary power generation process in a fuel cell, very few emissions are generated in the fuel processing sub-system and this is the only source of emissions in the FC-CHP. $\mathrm{NO}_{\mathrm{x}}$ pollution from the CHP system is less than from coal-fired electricity generation. $\mathrm{NO}_{\mathrm{x}}$ emissions from a diesel engine are in the range of 1.27-15 $\mathrm{kg} \mathrm{MWh}^{-1}$, from a natural gas engine in the range of 1.0-12.7 $\mathrm{kg} \mathrm{MWh}^{-1}$, from a micro turbine engine in the range of 0.18-1 $\mathrm{kg} \mathrm{MWh}^{-1}$ and from FC-CHP less than $0.01 \mathrm{~kg} \mathrm{MWh}^{-1}$ [53]. The source of $\mathrm{NO}_{\mathrm{x}}$ emissions in FC-CHP is a burner that supplies thermal energy for endothermic reforming processes by combustion of natural gas, if it is used as fuel. More advanced burner constructions have been developed to decrease emissions, for example an FLOX ${ }^{\circledR}$ burner operating on flameless oxidation, which ensures a quasi-homogenous temperature distribution in the combustion chamber. In this case the $\mathrm{NO}_{\mathrm{x}}$ emissions are low even at high air preheating temperatures. Methane $\left(\mathrm{CH}_{4}\right)$ can also be emitted as a consequence of incomplete combustion or as the result of leaks and losses during transportation. Emissions of $\mathrm{SO}_{2}$ and mercury compounds from burning natural gas are negligible. $\mathrm{SO}_{2}$ emissions are eliminated during FC-CHP operation because it is typically removed in an absorbed bed before reformate is processed. Table 5 summarises the industry-average levels of airborne pollutants like $\mathrm{NO}_{\mathrm{x}}, \mathrm{CO}$ and particulates from fuel cells, condensing boilers and CHP engines [54,55]. Measured emissions of airborne pollutants from fuel cells are around a tenth of those from other gas-burning technologies, as shown in Table 5.

Table 5

Measured emissions of airborne pollutants from fuel cells (averaged over 8 sources), condensing boilers and CHP engines; given in grams per MWh of fuel input $[53,54]$.

\begin{tabular}{llll}
\hline & Fuel cells & Condensing boiler & CHP engine \\
\hline $\mathrm{NO}_{\mathrm{x}}$ & $1-4$ & 58 & $30-270$ \\
$\mathrm{CO}$ & $1-8$ & 43 & $10-50$ \\
$\mathrm{CH}_{4}$ & $1-3$ & 13 & No data \\
$\mathrm{SO}_{2}$ & $0-2$ & 2 & No data \\
\hline
\end{tabular}

\subsubsection{Reduction of electricity costs}

$\mu \mathrm{CHP}$ offers benefits directly to the householder rather than to large energy suppliers. The electricity costs for the end user depend upon several factors such as: the cost of electricity generation, costs associated with subsidies for energy technologies, electricity transmission and distribution costs via the grid network and final retail to the customer. The unit price of electricity in the European Union (for household consumers with an annual electricity consumption of $2500-5000 \mathrm{kWh}$ ) ranges from $€ 0.087$ (US\$0.104) to $€ 0.298$ (US\$0.358) per $\mathrm{kWh}$, with an average price of $€ 0.184$ (US\$0.221) per kWh in 2011 [56]. The absolute unit price increase in the USA is lower than in the EU, though the percentage increase in the wholesale price is higher and predicted to be $50 \%$ by 2035 [57]. The electricity produced by FC-CHP systems has high economic value and it is almost 3.0-3.5 times better than natural gas power plants. FC-CHP converts a low cost fuel, typically natural gas, into high value electricity and in this way allows households to reduce their energy bills. The power produced from fossil fuels in power plants is generated at an efficiency of 35-37\% and about two-thirds of the primary energy is lost in the form of "waste" heat [1]. Centralized electricity generation and on-site heat generation has a combined efficiency of about $45 \%$, whereas cogeneration systems can reach efficiency levels of about $80 \%$. The transmission and distribution of electricity from large central power stations contributes to further losses of around $9 \%$ of net generation. This means that only about one-third is delivered to the end customer. Transmission and distribution losses will vary depending upon the distance between load and generator, the voltage, and the number of voltage transformation stages. According to World Bank Data, electric power transmission and distribution losses range from $1.82 \%$ to $54.60 \%$ (varying from country to country) and with a world average of $8.10 \%$ [58]. CHP is able to reduce power sector investments by up to $7 \%$ of the total projected power sector investment in the USA by 2030 . Providing on-site electricity generation that is resilient in the face of grid outages can provide power for critical services in emergencies and displace higher cost generation plants. CHP systems eliminate the economic losses related to the transmission and distribution of power. These energy savings reduce the capital costs of CHP electricity production and also reduce the delivery costs of the electricity to the end users. The Japanese grid electricity unit price is about $¥ 25 \mathrm{kWh}^{-1}$ (US\$0.225 $\mathrm{kWh}^{-1}$ ) which might be reduced to $¥ 6-7 \mathrm{kWh}^{-1}$ (US\$0.054-0.063 $\mathrm{kWh}^{-1}$ ) at night if the customer has a special contract with the utility company. Using natural gas, a fuel cell can generate electricity at a cost of only $¥ 10 \mathrm{kWh}^{-1}\left(\mathrm{US} \$ 0.089 \mathrm{kWh}^{-1}\right)$. Toshiba estimates that households using the FC-CHP systems will save between $¥ 40,000$ (US\$360) and $¥ 50,000$ (US\$450) per year on electricity costs [57].

\subsubsection{Grid independence}

Fuel cell systems have attracted market potential and may be able to solve grid outages. According to the US statistics, $80-90 \%$ of power failure originates from the distribution level [59]. The cost of power outages in the US is estimated at approximately US\$119 billion per year and non-disaster outages affect almost 50,000 electricity consumers [60]. Power outages may be due to failure of sensitive equipment like computers and other electronic devices during power fluctuations. The estimated annual cost of outages for a small commercial building is shown in Table $6[42,60]$. The cost of outages may be in range of US\$4000-6800 per hour for a commercial building with $100 \mathrm{~kW}$ load.

\subsection{FC-CHP disadvantages}

The important drawback of an FC-CHP system is the initial high 
Table 6

Estimated annual cost of outages for a $100 \mathrm{kWh}$ load small commercial building.

\begin{tabular}{|c|c|c|c|c|c|c|}
\hline Outage type & $\begin{array}{l}\text { Outage } \\
\text { duration }\end{array}$ & $\begin{array}{l}\text { Facility disruption } \\
\text { per outage }\end{array}$ & $\begin{array}{l}\text { Number of outages } \\
\text { per year }\end{array}$ & $\begin{array}{l}\text { Total annual facility } \\
\text { disruption }\end{array}$ & $\begin{array}{l}\text { Outage cost } \\
\text { per hour }\end{array}$ & $\begin{array}{l}\text { Total annual } \\
\text { cost }\end{array}$ \\
\hline Momentary interruptions & $5.3 \mathrm{~s}$ & $15 \mathrm{~min}$ & 4 & $1 \mathrm{~h}$ & US $\$ 4,000$ & US $\$ 4,000$ \\
\hline Long duration interruptions & $1 \mathrm{~h}$ & $2 \mathrm{~h}$ & 1 & $2 \mathrm{~h}$ & US\$4,000 & US $\$ 8,000$ \\
\hline Total & & & 5 & $3 \mathrm{~h}$ & & US $\$ 12,000$ \\
\hline
\end{tabular}

investment cost and strong market competition from other CHP power generation technologies. The cost of generation and systems availability are key factors in CHP technology selection. Up to now, the number of CHP units sold has been relatively small and the vast majority of non-portable fuel cells systems that are sold to consumers today are sold with the aid of a government subsidy [61]. The actual price of a $\mu \mathrm{FC}-\mathrm{CHP}$ system is currently about 30-50 times higher than United States Department of Energy (US DOE) targets. As of 2014, the purchase price of a $1 \mathrm{~kW}$ PEMFC or SOFC in Japan was US\$21,000-27,000, and prices from all manufacturers have fallen dramatically in recent years as shown in Table 7. The price of residential systems has decreased - the investment cost dropped by more than half in the period from 2009 to 2013 , i.e. by $85 \%$ in the last 10 years in Japan [18], and by $60 \%$ over the last four years in Germany [39]. The subsidies offered in Japan make up approximately $50 \%$ of the price of the installation of the unit. System costs may be reduced significantly over time but this relies upon the 'economies of scale' afforded by mass production. The price reduction of Japanese and South Korean PEMFCs are shown in Fig. 6 against the total number of installations to date, revealing a $\log -\log$ relationship known as "learning by doing". During demonstration projects in Japan and South Korea the price of residential PEMFCs fell by almost $20 \%$ for each doubling in cumulative production $[18,39,62]$. After commercialisation of the Japanese systems in 2008, the price fell by $13 \%$ per doubling. If the historic trends from Fig. 6 continue, one may expect in the future that millions of residential systems could be installed in the next 4-6 years with a cost of US\$7000-14,000. The cost of the back-up boilers in the FC-CHP system may account for $8-9 \%$ of the total investment cost of the CHP system. Panasonic reported a price reduction of around $30 \%$ in the latest model compared to the previous model; stating that it had reduced the fuel cell volume by $26 \%$, the weight by $10 \%$ and the catalysts content by $50 \%$, and with an increased durability of $20 \%$ (up to 60,000 h) $[63,64]$. Transparency Market Research forecasts suggest that the FC-CHP system market will grow by $27 \%$ per annum over the next 5 years, after which the payback period will have fallen to less than 5 years [42].

\section{Modelling the thermo-economic feasibility of FC-CHP systems}

FC-CHP modelling has received little attention over the past 10 years, especially in the analysis of the economic and environmental performance of the fuel cell. These models are classified as either simulation or optimisation models, and as either dynamic or steady state models. Here, simulations are useful in predicting the response and performance of the fuel cell system according to some pre-defined operating strategies and its interaction within its operating conditions.

\subsection{Simulation models}

Alanne et al. [64] investigated the viability of a SOFC system for a single-family house in Canada on the basis of a financial analysis by simulation modelling approaches. The study showed that low power (1-2 $\left.\mathrm{kW}_{\mathrm{el}}\right)$ SOFC systems seem to be feasible but are unacceptable for larger units due to significant amount of waste heat and are also unacceptable from an environmental point of view [65]. Staffell simulated the leading Japanese EneFarm systems operating in UK households to estimate the economic and environmental benefits of fuel cells in an emerging market [66]. The study showed that significant carbon savings can be achieved (as clearly seen in Fig. 5), but that economic benefits are marginal with present-day fuel costs, and thus a subsidy of $£ 0.10 \mathrm{kWh}^{-1}$ (US $\$ 0.16 \mathrm{kWh}^{-1}$ ) of electricity produced would be required to give an acceptable payback period.

Unfortunately, these types of models do not give any information on the optimisation of operation conditions or design of the fuel cell system. Optimisation models can be divided into two

Table 7

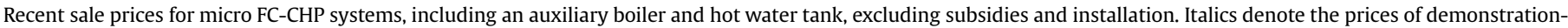
stage systems before their commercial launch [13].

\begin{tabular}{|c|c|c|c|c|c|c|c|c|}
\hline $\begin{array}{l}\text { FC } \\
\text { technology }\end{array}$ & Producer & $\begin{array}{l}\text { Output } \\
\text { power (W) }\end{array}$ & 2008 & 2009 & 2010 & 2011 & 2012 & 2013 \\
\hline \multirow[t]{4}{*}{ PEMFC } & Panasonic & 750 & & $\begin{array}{l}£ 20,900 \\
\text { (US\$33,000) }\end{array}$ & $\rightarrow$ & $\begin{array}{l}£ 16,200 \\
\text { (US\$25,900) }\end{array}$ & $\rightarrow$ & $\begin{array}{l}£ 12,100 \\
\text { (US\$18,900) }\end{array}$ \\
\hline & Toshiba \&Eneos & 700 & & $\begin{array}{l}£ 19,300 \\
\text { (US\$30,500) }\end{array}$ & $\rightarrow$ & $\begin{array}{l}£ 15,300 \\
\text { (US\$24,500) }\end{array}$ & & \\
\hline & GS \&FCPower & 1000 & $\begin{array}{l}£ 91,000 \\
(U S \$ 153,000)\end{array}$ & $\rightarrow$ & $\begin{array}{l}£ 52,000 \\
(U S \$ 72,800)\end{array}$ & $\rightarrow$ & $\begin{array}{l}£ 38,000 \\
(U S \$ 59,300)\end{array}$ & \\
\hline & Elcore & 300 & & & & $\begin{array}{l}£ 9000 \\
(U S \$ 14,400)\end{array}$ & $\rightarrow$ & $\begin{array}{l}£ 8000 \\
(U S \$ 12,500)\end{array}$ \\
\hline \multirow[t]{4}{*}{ SOFC } & $\begin{array}{l}\text { Vaillant, } \\
\text { Baxi\&Hexis }\end{array}$ & 1000 & $\begin{array}{l}£ 100,000 \\
\text { (US\$ } 168,000)\end{array}$ & $\rightarrow$ & $\begin{array}{l}£ 40,000 \\
\text { (US\$56,000) }\end{array}$ & $\rightarrow$ & & $\begin{array}{l}£ 26,000 \\
(U S \$ 40,600)\end{array}$ \\
\hline & Kyocera & 700 & $\begin{array}{l}£ 60,000 \\
(U S \$ 100,000)\end{array}$ & $\rightarrow$ & $\begin{array}{l}£ 38,000 \\
(U S \$ 53,000)\end{array}$ & $\rightarrow$ & $\begin{array}{l}£ 16,100 \\
\text { (US\$25,100) }\end{array}$ & \\
\hline & Eneos & 700 & & & & $\begin{array}{l}£ 15,800 \\
\text { (US\$ } 25,300 \text { ) }\end{array}$ & & \\
\hline & CFCL & 1500 & & & $\begin{array}{l}£ 22,700 \\
\text { (US\$31,800) }\end{array}$ & $\rightarrow £ 21,500 \rightarrow$ & $\$ 34,000)$ & $£ 19,600$ (US\$26,400) \\
\hline
\end{tabular}




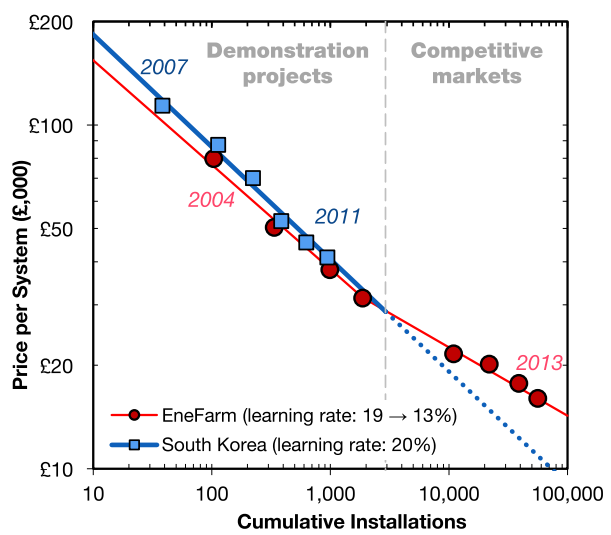

Fig. 6. Learning curves fitted to historic prices of Japanese and South Korean residential PEMFCs. Each doubling in production saw prices fall 19-20\% during demonstration projects, and 13\% after commercial launch in Japan [18,62].

types: one is an optimal operation model or unit commitment model and the other one is a pinch-point design model.

\subsection{Optimal operation models}

Unit commitment is a large scale optimization problem that determines the operating status of hundreds of produced units based on a set of complicated constraints. El-Sharkh et al. [66] developed a unit commitment model for finding optimal power output from a PEMFC based power plant. The proposed technique seem to be more effective for power plants with a power output range of 4-15 kW as it compared the results of a genetic algorithm technique [67]. The same author later developed a model which is based on hybrid evolutionary programming and a Hill-Climbing based approach to analyse the impact of price/tariff fluctuations on the optimal cost of operation of a PEMFC power plant operating in a grid-parallel mode [68]. It was shown that the fuel and hydrogen selling prices as well as residential gas prices have significant effects on the system operational strategies. The production levels and cost of components are sensitive to price changes during low thermal demand periods, while others are sensitive during high thermal load periods. Hawkes et al. [68] developed a detailed techno-economic energy-cost minimization model of a $\mu \mathrm{CHP}$ system drawing on steady-state and dynamic SOFC stack model and power converter design. A non-linear programming technique applied to identify minimum costs and stack capacities under various current density change constants. It was found that constraints on the rates of change in current density are not an important design parameter from an economic point of view [69]. Cost-effective operating strategies for residential micro-combined SOFC systems have been investigated by the use of a non-linear programming technique and it was demonstrated that hypothetical operating strategies such as electricity demand can result in poor performance [70]. Ferguson and Ugursal [70] developed a steady state model to predict size and performance of the PEMFC system for houses. Results indicated that fuel cell size and operating strategies are critical factors affecting the performance of fuel cell based cogeneration systems [71].

\subsection{Pinch-point design models}

Pinch-point optimization defines the minimum energy required and sets the basis to design the ideal heat-exchanger/recovery network. Marechal et al. [71] developed a pinch-point multiobjective optimization technique applied on a combination of fuel cell and gas turbine concepts that allow efficiencies of $48-54 \%$ to be reached with a predicted market cost of US\$450-2000 $\mathrm{kW}^{-1}[72]$. Palazzi et al. [72] developed a similar thermo-economic model to compute integrated system performances, sizes and costs based upon the pinch-point optimization technique. This mixed integer non-linear programming model was applied to the design of a $50 \mathrm{~kW}$ SOFC based system, with different and optimized fuel processing options. Two objectives were taken into consideration, namely: minimization of the specific cost and maximization of efficiency [73]. Wallmark and Alvfors [73] formed a pinch-point design of a $15 \mathrm{~kW}_{\mathrm{el}}$ PEMFC cell system supplying a building in Sweden with heat and power [74]. Although pinch-point analyses are critical for refining the technical design of CHP systems, they are not able to provide a direct link between design and economic/ environmental performance. Godat and Marechal [74] developed a PEMFC based CHP model including three sub-systems and the model was used to analyse the efficiency with respect to steam-tocarbon ratio, steam reformer temperature, fuel cell temperature and fuel utilization [75].

\section{Technical potential of PEMFC and SOFC technology for CHP applications}

\subsection{CHP system efficiency}

The electrical and total CHP system efficiencies vary with electrical/thermal loads and the type of fuel cell that is used. Fuel cell system, electrical and thermal efficiencies are a direct function of the stack load.

\subsubsection{Overall efficiency}

Fuel cells have higher electrical efficiencies than other CHP technologies at small scale power range which is typical for domestic applications [9]. The best gas turbine plants can operate at $60 \%$ gross efficiency [76], but fuel cell auxiliary power requirements lower this to a net efficiency of $\sim 55 \%$ [77]. Centralized power plants also entail additional losses from the transmission and distribution of electricity, bringing the net efficiency of gas to the end user down to $\sim 52-54 \%$ [78]. If power plants operate at partial load conditions the net efficiency is further reduced [76].

High SOFC electrical efficiencies can be achieved at levels of up to $45-60 \%$ with total efficiencies of $85-90 \%$ [79]. For example, CFCL reported their micro-CHP system (BlueGen) with an AC efficiency of $\sim 60 \%$ including auxiliary losses. SOFC operating at higher electrical efficiencies are not able to provide optimal solutions for electrical and thermal efficiencies and lower electrical efficiencies ( $35 \%)$ may be achieved by operating at higher current density and it may be a more attracting solution for residential users [80]. SOFCs running at sub-optimal conditions are also able to beat modern power plant technologies, without considering the thermal energy as co-product.

In the case of LT-PEMFC systems, their electrical efficiencies may reach up to $\sim 39 \%$ at rated power and considering the CHP energy generation mode, efficiencies of up to $~ 90-95 \%$ can be achieved $[64,81]$. The power generation efficiencies of an LT-PEMFC with a reformer system show that it is not an ideal combination during operation [10]. For example, the electrical efficiency of an LT-PEMFC is higher when compared to an HT-PEMFC (the overall efficiency $=$ electricity efficiency + thermal efficiency is higher for HT-PEMFC). The quality of the HT-PEMFC heat output is high compared to the LT-PEMFC, as the HT-PEM fuel cell system can deliver hot water up to $80^{\circ} \mathrm{C}$. The US DOE targeted total fuel cell CHP system efficiency of $90 \%$ by 2020 [82]. Currently, EU residential systems have an electrical efficiency of $\sim 30-35 \%$, which is lower than the leading Japanese and Australian systems [39]. 


\subsubsection{Stack vs. system efficiency}

Fuel cell efficiency is determined as the ratio of the stack electrical power to the $\mathrm{H}_{2}$ thermal power entering the stack. Usually the system's electrical efficiency decreases while its thermal efficiency increases with load [12]. Both electrical and thermal efficiencies are important for CHP system operations (based upon seasonal variations, grid connectivity etc.). Most CHP manufacturers are focussing on the electrical efficiency of CHP systems with the excess of electrical energy being stored in batteries or being sold to the gird. As previously stated, fuel cells have the advantage of having higher electrical efficiencies compared to other CHP technologies at small scale power range which is typical for domestic applications. The fuel cell stack efficiency is an isolated efficiency and the CHP system efficiency is the complete efficiency of the system. The CHP system efficiency includes the efficiencies of the fuel cell stack, the fuel processor, the power conditioning devices as well as parasitic losses related to the power consumed by the BoP components. The typical breakdown of a $\mu \mathrm{FC}-\mathrm{CHP}$ system is shown in Fig. 7. A fuel cell stack with an electrical efficiency of $~ 65 \%$ typically gives a CHP system net electrical efficiency of $\sim 34 \%$. Most of the efficiency losses in an FC-CHP system are associated with auxiliary sub-systems e.g. pumps, fan/blower, fuel processor and controllers. All these losses amount to $20-33 \%$ of net electrical efficiency loss in the FC-CHP system [55]. The HT-PEMFC stack needs less auxiliary power devices compared to an LT-PEMFC stack as an HT-PEMFC does not require humidified gas.

\subsubsection{Part-load efficiency}

When the fuel cell stack runs at partial load, the efficiency increases as stack cell voltages raise lower current densities. This rise is not seen in complete FC-CHP systems though due to parasitic losses in the fuel processing and other auxiliaries. The electrical and thermal efficiencies of SOFC and PEMFC CHP systems are plotted against the power output in Fig. 8 [45]. The SOFC electrical efficiency decreases slightly with increasing power output and the thermal efficiency increases with the power output. The PEMFC electrical and thermal efficiencies increase as power output increases. The PEMFC electrical efficiencies can be easily improved by choosing a fuel cell operating at higher cell voltages (i.e. lower current densities); however this chosen strategy leads to an extra investment cost as more single cells (in the stack) are required for a given power output. At partial load conditions both LT- and HT-PEMFC systems have similar electrical efficiencies but the HT-PEMFC requires much simpler BoP components for its operation.

\subsection{Transient response characteristics and optimal operational time}

If the FC-CHP system is grid connected and operates in a gridparallel mode, the grid would deliver supplementary power during transient operations. If the FC-CHP system operates in a gridindependent mode, the use of batteries (e.g. redox flow batteries) or super-capacitors is needed to provide the power required during transient operations. The transient response time for LT-PEMFC stack is typically less than $10 \mathrm{~s}$ and the expected time for the reformer is up to $100 \mathrm{~s}$. The transient response times for battery/ super-capacitor are less than $10 \mathrm{~s}$. A fuel cell stack transient response time of $15 \mathrm{~min}$ for SOFC technology has been reported but may not be an issue if the system operates in a grid-parallel mode [14]. Different seasonal heat demands require an optimal number of operational hours for each season. For example, a $370 \mathrm{kWh}$ monthly average electricity demand of an apartment in South Korea requires the following optimal operational times for a $1 \mathrm{~kW}_{\mathrm{el}} \mathrm{LT}$ PEMFC based CHP system $-21 \mathrm{~h}$ in spring, autumn and winter and $3 \mathrm{~h}$ in summer [83].

\subsection{Start-up time}

The start-up time of the FC-CHP system mainly depends upon the start-up time of the reforming process which typically is a steam reformer, partial oxidation or auto-thermal reformer as well as the fuel cell stack pre-heating time. The steam reformer start-up time is typically less than $\mathbf{3 0}$ min from ambient temperature (the start-up time is projected to decrease to less than $10 \mathrm{~min}$ by 2015). PEMFC stacks have much shorter start-up times compared to SOFC stacks. The stack start-up times for SOFCs varied from $2.5 \mathrm{~h}$ to $20 \mathrm{~h}$ which is well beyond the US DOE 2008 status of 60 min. HT-PEMFC systems can be cooled down and heated up with cathode air (for up to $1 \mathrm{~kW}_{\mathrm{e}}$ stacks) which can be used to pre-heat the stack during start-up. Pre-heated air through the fuel cell stack means less time is required to heat up the stack. The liquid cooled fuel cell stack

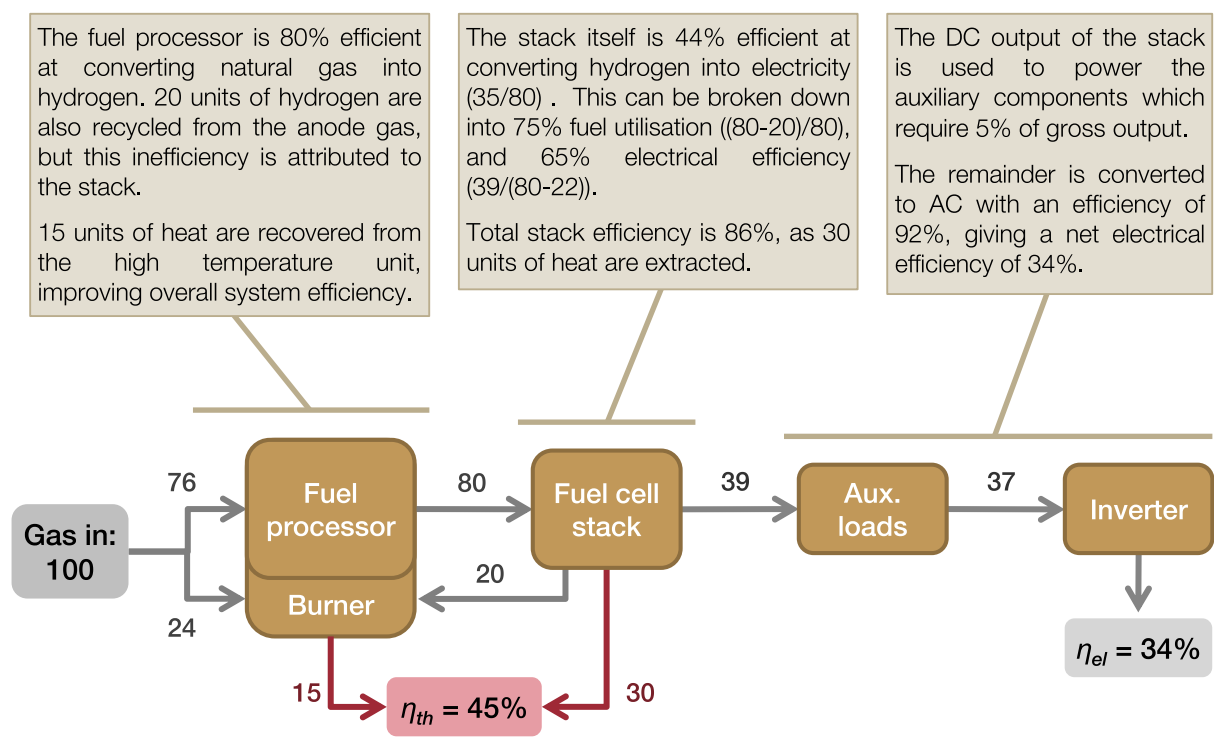

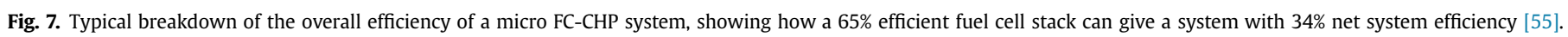



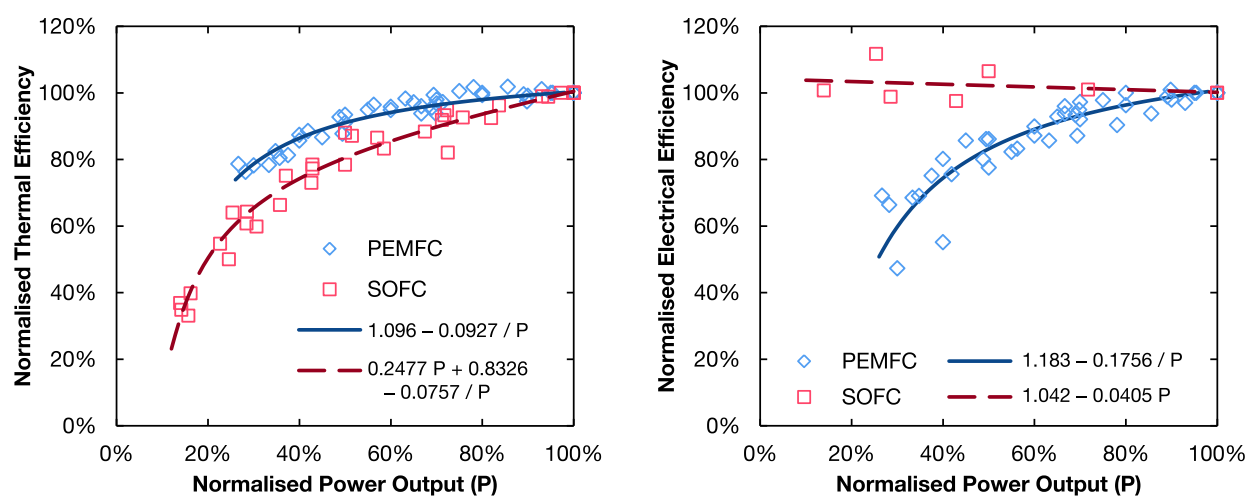

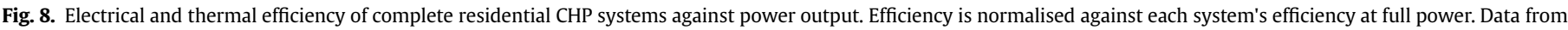
8 PEMFC and 6 SOFC systems [45].

requires an additional system setup to heat the stack but enhances the start-up time of the HT-PEMFC stack $[84,85]$.

\subsection{Degradation}

Fuel cell degradation rates can be expressed in two modes: one related to energy output (degradation rate proportional to power density), and the other one is related to cumulative thermal cycles (degradation rate proportional to cycling rate). The fuel cell degradation rate depends upon the fuel cell stack design, materials used, control system design, operating temperatures and type of fuel cell used. By keeping the degradation rate within acceptable levels, the fuel cell performance remains acceptable throughout the operational life of the system. Degradation of the fuel cell performance originates from various physical-chemical mechanisms that are involved in all of main fuel cell components (catalyst, membrane, electrodes etc.); a declining performance of one subcomponent may lead to the degradation of the others. Degradation mechanisms may be reversible, partially reversible or irreversible and may be aggravated by, for example the cycling of temperatures, power loads, potentials, cell voltages, electrode oxidation load etc. Studies show that if the cell voltage falls by $0.5-2 \%$ per $1000 \mathrm{~h}$, the power output and electrical efficiencies would fall by $\sim 2.5-10 \%$ per year [55]. In recent years, degradation rates have reduced to $0.1-1.5 \%$ per year in leading LT-PEMFCs $[86,87]$ and $1.0-2.5 \%$ per year in SOFCs [88-91]. End of Life (EoL) is defined as power output dropping by $20 \%$ of the initial specifications i.e. Beginning of Life (BoL). In general, the EoL of a fuel cell may occur after 10-20 years' operating time. At the EoL of a SOFC, a $35-40 \%$ drop in electrical efficiency is often observed.

\subsection{Operating lifetime}

For stationary applications, it is assumed that the fuel cell systems should be capable of a minimum life time of $40,000 \mathrm{~h}$ (with 8000 h of uninterrupted service at $>80 \%$ rated output power) [92]. Panasonic recently reported an increased durability in their LTPEMFC CHP systems to $60,000 \mathrm{~h}$ and other Japanese CHP companies now are guaranteeing up to $80,000 \mathrm{~h}[63,64,81]$. SOFC stacks have demonstrated up to 30,000 h durability and single cells up to $90,000 \mathrm{~h}[88]$. EneFarm systems are currently sold in Japan with a 10 year warranty with free maintenance and repairs. Other residential systems (EU) are sold with a guaranteed life time of $10,000-20,000 \mathrm{~h}$. A significant improvement in the life time of the fuel cell systems has been observed over the past 15 years, as shown in Fig. 9 [45]. Manufacturers' guarantees data are fitted to exponential curves, indicating that PEMFC lifetime may increase with a rate of $22 \%$ per year and SOFC with a rate of $16 \%$ per year. In the literature, the longest lifetime reported for an HT-PEMFC is $18,000 \mathrm{~h}$ under steady-state conditions; this is indeed quite low compared to LT-PEMFC systems [93,94].

\section{FC-CHP system main components}

The FC-CHP system consists of various sub-systems and components e.g. the fuel cell stack, fuel processor, DC/AC inverter, heat exchanger and control systems. A schematic diagram of an FC-CHP system and associated components is shown in Fig. 10 [34]. The operating conditions of each component are discussed in the following sections.

\subsection{Fuel cell stack}

The fuel cell stack converts the chemical energy of hydrogen into electricity, producing heat and water as a by-product. The Membrane Electrode Assembly (MEA) is the "heart" of every fuel cell stack and this component determines the stack operating conditions and influences its performance. The LT-PEMFC stack can operate in the range of $60-120^{\circ} \mathrm{C}$ but only operating at temperatures below $80{ }^{\circ} \mathrm{C}$ ensures its long lifetime. One of the disadvantages of the LT-PEMFC is the need for the humidification of reactants making water management quite complex and difficult. Another issue is the high sensitivity to the CO content in the anodefed gas. High purity hydrogen fuel is required and only a CO content of $<10 \mathrm{ppm}$ is permitted [95]. Higher levels of CO can lead to irreversible platinum $(\mathrm{Pt})$ catalyst degradation. In order to

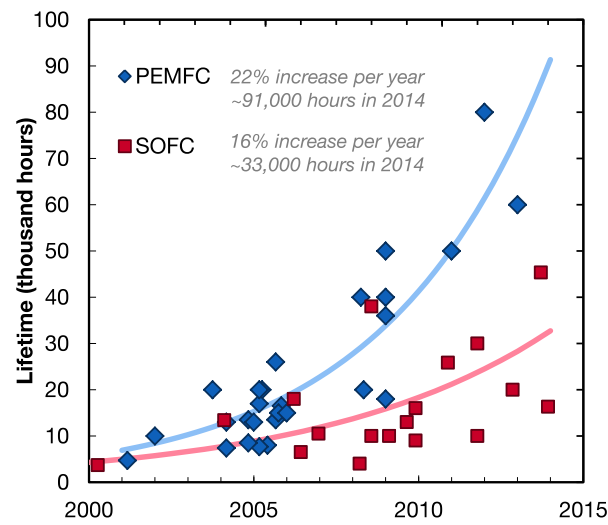

Fig. 9. The improvement in fuel cell system lifetimes over the past fifteen years. Data from 12 PEMFC and 9 SOFC systems [45]. 


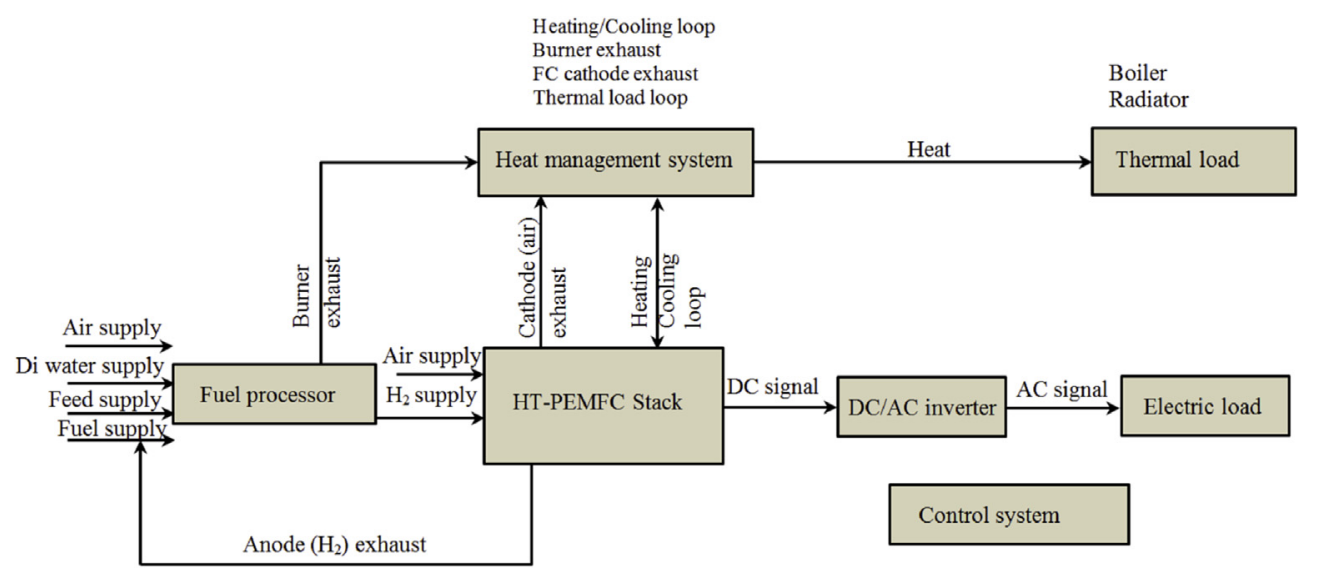

Fig. 10. Schematic diagram of HT-PEMFC based micro FC-CHP system [34].

overcome this issue, higher operating temperatures need to be used. Increasing the operating temperature of the PEMFC should effectively alleviate $\mathrm{CO}$ adsorption on the catalyst, but the membrane needs to be replaced with high temperature resistant materials like polybenzimidazole (PBI). An HT-PEMFC with a PBI membrane can be operated up to a temperature of $200^{\circ} \mathrm{C}$. At this temperature, high CO tolerance $(<5 \% \mathrm{CO})$ is observed and humidification of reactants is no longer required [96,97]. During the operation, no liquid water is present in the HT-PEMFC stack which in turn increases the reliability of the stack. HT-PEMFCs can be operated in dead-end anode operation enabling a simple system design with low parasitic losses. SOFC stacks typically operate at $550-1000{ }^{\circ} \mathrm{C}$ with very high CO tolerances. Two types of fuel cell stacking approaches are used: one is axial in-series and the second is tubular bundles. Most SOFC stacks use planar cell construction and in some cases they have tubular designs.

The Pt used for the electrodes in PEMFC systems is often thought to be a major problem because of its high initial cost. However, prolonged research into optimum catalyst design means that total platinum loadings have fallen to around $0.4 \mathrm{mg} \mathrm{cm}^{-2}$ [98], equating to around $0.1-0.2 \mathrm{~g}$ per $\mathrm{kW}$ [45]. Using 2012 prices for Pt (US $\$ 1500$ $\left.\mathrm{oz}^{-1}\right)$, Pt costs constitutes $10-15 \%$ of the stack price, and thus only $2-3 \%$ of the whole system price [18]. The cost of Pt catalyst used in the stack is expected to remain similar in the future, constituting only $12.6 \%$ of the total system price in 2045 [99].

Global reserves of Platinum Group Metals (PGMs) amounts to around 48,000 tonnes [100], while demand for Pt stands at around 200 tonnes per year [101]. The largest demands for Pt come from catalytic converters in the automotive industry (about $40 \%$ ) and jewellery (30-40\%) [102]. Installing a $1 \mathrm{~kW}$ PEMFC in every American home would require 40 tonnes of $\mathrm{Pt}$ (assuming $0.3 \mathrm{~g} \mathrm{~kW}^{-1}$ for the whole system), adding around $2 \%$ to global Pt demand if replaced once every 10 years. Pt demand is covered by "virgin" mined Pt as well as recycled Pt supply. The total Pt loss over a fuel cell system's lifetime and the Pt recovery process is estimated to be $10 \%$ [98]. It can be safely concluded that the commercialisation of fuel cells will not affect significantly the Pt demand/supply balance [103].

\subsection{Fuel processor}

The choice of the fuel influences the efficiency and cost of the FC-CHP system. The fuel processor is one of the most significant components, estimated to contribute around $80 \%$ of the BoP costs in an FC-CHP system [18]. A fuel purification sub-system also adds to the additional cost, e.g. fuel desulfurization sub-system for SOFC and CO removal sub-system for LT-PEMFC [14]. There are two strategies for the fuel supply to the fuel cell. The first option is to supply the hydrogen directly and the second option is on-site conversion of the fuel into hydrogen or hydrogen rich gas which is called decentralized hydrogen production, but both come at a high initial investment cost. On-site fuel conversion is expensive and it requires complex reactor designs. However decentralized hydrogen production eliminates the need for a costly $\mathrm{H}_{2}$ distribution infrastructure. In general though, it is less efficient and more expensive than centralized hydrogen production. The cost of decentralised $\mathrm{H}_{2}$ production may exceed US $\$ 50 \mathrm{GJ}^{-1} \mathrm{H}_{2}$ [104]. $\mathrm{H}_{2}$ is mainly produced from fossil fuels and currently $48 \%$ is produced from natural gas, 30\% from refinery/chemical off-gases, $18 \%$ from coal and the rest is produced by water electrolysis process (4\%). There is a growing interest in centralizing $\mathrm{H}_{2}$ production and supply in the EU and USA; which may simplify hydrogen supply to the stationary fuel cell systems.

Natural gas (methane $-\mathrm{CH}_{4}$ is a predominant compound) is often assumed to be the fuel of choice for baseline residential or stationary CHP applications in countries like the UK, Germany and Japan, because they have well established gas distribution pipelines. For residential applications, in addition to natural gas, propane gas or LPG are also potential fuels for on-site reforming for fuel cells $[105,106]$. Natural gas can be converted into $\mathrm{H}_{2}$ by using various fuel processors that include Steam Reforming (SR), Partial Oxidation (PO) and Auto Thermal Reforming (ATR) [107]. An overview of fuel processing for fuel cell systems is shown in Fig. 11. The fundamental differences in all three types of reformers are the source of oxygen and/or water used to combine with the carbon within the fuel to release the $\mathrm{H}_{2}$ gas and the thermal balance of the chemical process. The chemical reactions for each process step to produce $\mathrm{H}_{2}$ from natural gas can be written as:

SR:

$\mathrm{CH}_{4}+\mathrm{H}_{2} \mathrm{O} \rightarrow \mathrm{CO}+\mathrm{H}_{2} \Delta H=+206 \mathrm{~kJ} \mathrm{~mol}^{-1}$

PO:

$\mathrm{CH}_{4}+0.5 \mathrm{O}_{2} \rightarrow \mathrm{CO}+2 \mathrm{H}_{2} \Delta H=-36 \mathrm{~kJ} \mathrm{~mol}^{-1}$

ATR:

Combination of $\mathrm{PO}$ and SR reactions

Steam reforming uses steam and it requires a substantial amount of heat as an input due to extremely endothermic 


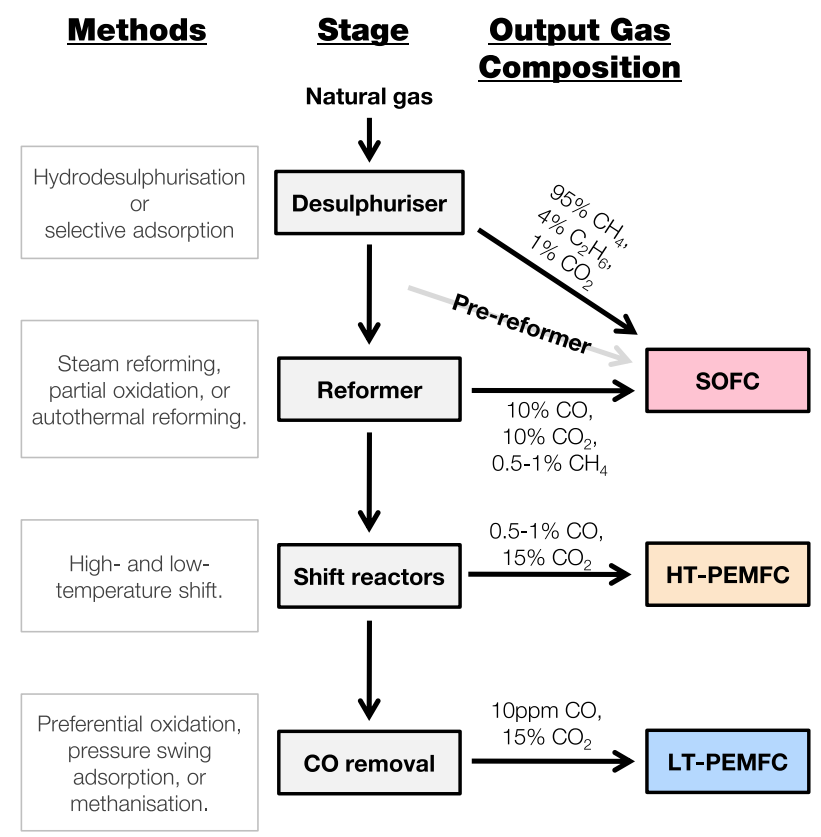

Fig. 11. An overview of fuel processing for fuel cell systems [55]. Moving from top to bottom shows the chain of processing stages from natural gas to hydrogen that is suitable for SOFC, HT- and LT-PEMFC systems.

reactions. At higher temperatures, SR operation achieves higher conversion with commercial catalysts like nickel $(\mathrm{Ni})$ and ruthenium $(\mathrm{Ru})$ pellets. While PO units use oxygen gas to combust a portion of the fuel, the thermal balance is exothermic and releases heat. $\mathrm{PO}$ is an attractive process due to the rapid reaction rates (up to $1,200,000 \mathrm{~h}^{-1}$ ) [108]. For fuel cell applications, the PO reaction has an advantage over the complete combustion reaction as it produces larger amounts of $\mathrm{H}_{2}$ and $\mathrm{CO}$ (which is further used to generate $\mathrm{H}_{2}$ via the Water Gas Shift Reaction - WGSR) as well as heat (used for hot water or preheater for PO gas feeder or other fuel processing reformer like ATR). ATR reformers uses exothermic heat (generated from the exothermic PO reaction) to supply the heat required for the endothermic SR reaction. ATR based reformers use both steam and oxygen and are typically operated at or near the thermal neutral point and therefore do not generate or consume thermal energy. A typical natural gas reformer can achieve efficiency in the range of 75-90\% (calculated for Lower Heating Value - LHV) while a range of $83-85 \%$ is expected. SR has a rich $\mathrm{H}_{2}$ concentration of $70-80 \%$, compared with $50-60 \%$ using an ATR based reformer and even lower for PO [109].

Natural gas with SR exhibits the highest fuel cell system efficiency in comparison to other hydrocarbon fuels such as gasoline or diesel [110]. Using an SR, with the highest conversion efficiency, may yield a saving of up to $30 \%$ in fuel compared to other methods [111]. SR is a highly endothermic reaction $\left(-206 \mathrm{~kJ} \mathrm{~mol}^{-1} \mathrm{CH}_{4}\right)$ and it is generally carried out at $700-800{ }^{\circ} \mathrm{C}$. Thermal energy required for endothermic SR reactions can be generated in the fuel processor by the integrated combustion burner that uses the same gas as the reformer. In FC based systems, the anode off-gas is directed to the burner whereby the chemical energy of $\mathrm{H}_{2}$-rich gas is converted into heat. This solution increases the overall efficiency of the FCCHP system. Because of the high temperature of the endothermic reaction, SR prevents rapid start-up and transient performance compared to other methods $[109,112]$. The SR process is limited by the heat transfer rate on the catalyst surface; therefore heat transfer is a critical factor to accelerate the chemical reaction. The space velocity for SR is typically in the order of $5000-8000 \mathrm{~h}^{-1}$ (on a wet feed basis) and it requires a large volume of catalyst bed. To enhance the chemical reaction, the pressure drop across the catalyst bed should be low - it can be minimized by increasing the pellet size, but this lowers the effectiveness of the catalyst. Engelhard Corporation reported a higher $\mathrm{CH}_{4}$ conversion by depositing a precious metal catalyst onto a metal monolithic substrate [113]. The precious metal catalyst enables faster heat conduction, increasing thermal efficiency in the catalyst reactor and reducing the volume of the catalyst bed. This in turn reduces the pressure drop in the reactor, which favours the reaction to proceed with high space velocity. Therefore, the precious metal monolithic catalysts could be used to improve the size and safety of the reformers and simplify the BoP, provided they can endure transient and cyclic start/stop operations (and offer low backpressure) [108]. The major drawback to the use of precious metals is invariably high expense cost [114].

SR can be performed in PEMFC based FC-CHP as an "external" reforming process and in systems based on high temperature fuel cells, such as MCFC and SOFC, as an "internal" process. Internal reforming reduces the overall system size and cost of the fuel processor sub-system. Commercially available SOFC based FC-CHP systems use a pre-reformer to avoid excessive thermal stress and to increase operating lifetime [115]. For internal reforming in SOFC based systems, the fuel processor consists of a reformer and a desulfurization unit; whereas the PEMFC fuel processor is composed of a large reformer and a CO clean-up component (which is not required for HT-PEMFC), made up of two water gas shift reactors and one preferential CO oxidation reactor [116,117]. HTPEMFC allows lower quality $\mathrm{H}_{2}$-rich reformate and requires a simpler fuel processing sub-system with a coupled steam methane reformer and a single-stage temperature water gas shift reactor.

The reformate stream composes of $\mathrm{H}_{2}, \mathrm{CO}_{2}$ and a portion of $\mathrm{CO}$ (typically $0.5-10 \%$ ) as well as sulphur compounds. Both $\mathrm{CO}$ and sulphur compounds are poisonous to LT-PEMFCs, while SOFCs and HT-PEMFCs are able to tolerate CO gas but are highly sensitive and not resistant to sulphur. Sulphur is generally removed using $\mathrm{ZnO}$ or an adsorption technique such as activated carbon. Other desulphurization techniques exist but are not suitable for small scale applications [9]. Desulfurization units need to be changed periodically and this operation results in additional maintenance cost. The sulphur content of natural gas is typically $<0.1 \mathrm{ppm}$ and it varies between countries, for example, $<1 \mathrm{ppm}$ in Germany, $<3.3 \mathrm{ppm}$ in the UK [118]. A PEMFC fuel processor is complicated and each stage of the fuel processing requires temperature control and thermal integration. In addition to an SR, PEMFC requires a shift reactor. The outlet of the reformer gas contains $6-15 \%$ CO and this CO can be converted to $\mathrm{H}_{2}$ via the water gas shift reaction (4).

$\mathrm{CO}+\mathrm{H}_{2} \mathrm{O} \rightarrow \mathrm{CO}_{2}+\mathrm{H}_{2} \Delta H=-41 \mathrm{~kJ} \mathrm{~mol}^{-1}$

Due to a better CO conversion at the shift stage the process runs practically with a surplus of water of $50 \%-100 \%$. This is expressed as steam to carbon ration $(\mathrm{S} / \mathrm{C})$ of 3-4. This surplus of water leaves the process as steam and leads to a dew point of the reformate gas of about $65{ }^{\circ} \mathrm{C}-80{ }^{\circ} \mathrm{C}$. Shift reaction operating temperature depends upon the dew point, catalytic kinetics, and catalyst stability, and is performed in the two adiabatic stages, High-Temperature (HTS) and Low-Temperature (LTS) Shift. The reformate gas enters the HTS catalyst (chromium oxide-stabilized iron oxide catalyst) at temperature of $350-450{ }^{\circ} \mathrm{C}$ and exits with temperature of $400-500{ }^{\circ} \mathrm{C}$ containing $3-4 \% \mathrm{CO}$. The outlet of HTS gas is cooled to $200{ }^{\circ} \mathrm{C}$ and fed to LTS catalyst (CuZn) and outlet concentration of CO is reduced to about $0.2-0.5 \%$. In shift reactors, the $\mathrm{CO}$ produced at the reformer is converted to $\mathrm{CO}_{2}$ in the Selective Methanation (SelMeth) or the Preferential Oxidation (PrOx) process. In most cases the methanation process is used due to many advantages regarding power consumption, cost reduction, integration and 
efficiency. The methanation reaction is described by the following reaction (5):

$\mathrm{CO}+3 \mathrm{H}_{2} \underset{\text { T,catalyst }}{\longrightarrow} \mathrm{CH}_{4}+\mathrm{H}_{2} \mathrm{O}$

This process is sensitive to temperature and has to be performed at temperature range from 200 to $230{ }^{\circ} \mathrm{C}$. Other techniques like selective oxidation of $\mathrm{CO}$ and oxygen bleed can be used to reduce the CO concentration. HT-PEMFCs have an advantage over the LTPEMFCs because they can be operated with low quality reformed $\mathrm{H}_{2}$ as a fuel. In LT-PEMFC based systems, two or more CO purification stages are required to obtain a $\mathrm{CO}$ concentration lower than $10 \mathrm{ppm}$, whereas HT-PEMFC based systems require only a single CO purification step. The performance loss of HT-PEMFC operating with low quality reformate (up to $5 \%$ CO) is very low $[119,120]$. For high temperature fuel cells, such as MCFC and SOFC, the waste heat is available at the reforming temperatures, so there is no drop in electrical efficiency. It is also advantageous to perform at least a part of the reaction in an "internal" reformer within the stack, which helps to provide stack cooling whilst keeping the cell temperature uniform. Waste heat from the PEMFC is not available at reforming temperatures, so supplemental heat is provided by burning the fuel, which affects total efficiency.

\subsection{Thermal management}

Heat recovery from the fuel cell is essential in order to improve the total system efficiency, performance and durability of the fuel cell system. Thermal management options for PEMFC and SOFC vary due to their operating temperatures and exhaust air temperatures. LT- and HT-PEMFCs' heat is recovered by circulating liquid coolant through the internal or external cooling system [121-127]. The heat recovered of a PEMFC stack can be used for space heating and hot water heating. In a PEMFC system an after-burner (used to burn unreacted fuel) can also be employed to create a higher heat output and to increase the overall efficiency. Heat recovery from a SOFC is more complex - it is realized by supplying the cathode with excess air. The excess cathode air and unconsumed fuel in the stack are combusted in a burner and the produced heat is used for preheating the reactants supplied to the reformer or the fuel cell stack. Large quantities of air are required for reactant air preheating and for cooling. The air is usually supplied to the fuel cell stack by an 'air' blower. Industrial air blowers are generally inefficient and can consume significant amounts of power, taxing the system's electrical efficiency. More efficient, cost-effective blowers are desirable for SOFC technology. Low-cost heat exchangers are desirable for heating or cooling of various gas streams with $\mathrm{CHP}$ systems.

\subsection{Power conditioning}

Inverters and converters are used to condition the non-linear DC electrical output of the fuel cell stacks to be useful for the end-user power requirements. Depending upon the fuel cell electrode area and the number of single cells in the stack, the DC output of the stack varies. During operation, the cell voltage of each individual cell decreases with increasing electrical load and the output is considered as an unregulated voltage source. In the power conditioning sub-system, the output stack voltage can be boosted to provide a regulated higher voltage input source to an electronic inverter. The DC/AC inverter commonly uses a pulse width modulation technique at high frequencies to generate simulated $\mathrm{AC}$ output. The efficiency of power conditioning equipment is inversely proportional to the cost and also depends upon the fuel cell output characteristics. The inverter efficiency is typically around 85-95\% for a $10 \mathrm{~kW}_{\mathrm{el}} \mathrm{FC}-\mathrm{CHP}$ system [9]. The AC electrical power can be used for home applications and the excess of produced energy can be fed back into the grid if the system is running in a grid-parallel mode or it can be stored in batteries for future use.

\subsection{Balance of plant (BoP) components}

The cost of BoP components is significantly higher per $\mathrm{kW}$ of system power for low power systems, especially at the $1-2 \mathrm{~kW}$ range. As the system size and the annual manufacturing rate increases, the system cost decreases [128]. The overall cost of the FCCHP system includes the fuel processor, the fuel cell stack and the power conditioning as well as other components such as pumps, blowers, control valves, sensors, pipes and heat exchangers. While the above-mentioned parts are common for every FC system, there are some unique parts that are needed for different FC technologies. For example, HT-PEMFC based systems require an additional activated carbon bed to capture fugitive phosphoric acid from the fuel cell stack to prevent the fouling of catalysts. LT-PEMFC based systems require installation of a de-ionizing filter to remove metallic contaminants from the coolant and the coolant heat exchanger that is used to allow heat transfer to the building heat loop. SOFC based FC-CHP systems require heat exchangers for pre-heating of reactants, and these heat exchangers operate at relatively high temperatures which is often more costly than other systems.

\section{Conclusions}

Micro-CHP systems are attractive solutions for decentralized electrical energy production with high efficiency. This review paper describes micro FC-CHP technologies and focuses on their applications. FC based CHPs are the most beneficial and promising technology for cogeneration. The technology has many advantages that may solve current issues related to energy generation but it is not problem-free. Currently, the main disadvantage is the high initial investment cost, this is mainly attributed to the low production volume. During many demonstration projects, the Japanese case shows that by doubling the production, it is possible to reduce the price of FC-CHP by $~ 25 \%$, and a further $13 \%$ reduction could be achieved after commercialisation. Many countries are developing policies that support and promote the use of FC-CHP systems for instance by implementing subsidies. Many research, development and demonstration (RD\&D) programmes focus on the development and commercialisation targets of thousands (1000's) of FC-CHP systems worldwide. Based upon techno-economic analyses and the energy demands, the most suitable and targeted market for FCCHP systems is in the residential sector where units up to $1 \mathrm{~kW}_{\mathrm{el}}$ power could be used for electrical energy and heat generation. Modelling the current state of development of the technology show that the most suitable fuel cell technologies that might be used for cogeneration are SOFC and PEMFC. Currently those two fuel cell technologies are used in FC-CHP systems for residential applications. SOFC can deliver high quality heat operating at high temperatures but suffers from longer start-up times. Moreover the temperature cycling for this type of fuel cell is an issue which negatively influences its lifetime. Cogeneration systems based on LT-PEMFC technology show very high efficiencies and reliability. The high power density of the LT-PEMFC is definitely the main advantage but one of the main issues is the complex water management and thus BoP as well as the need to supply high purity fuel. HT-PEMFC technology might be a very good alternative as it exhibits comparable performance and cost reduction on the system level which is achievable due to simplification of the system layout (some of the sub-systems and system components are not required). 


\section{Acknowledgements}

The support of the Hydrogen and Fuel Cell Technologies RDI Programme (HySA), funded by the Department of Science and Technology in South Africa (Key Programme 1 Combined Heat and Power) is gratefully acknowledged, as is the support of the UK Energy Research Centre Phase III (EP/L024756/1) for IS.

\section{References}

[1] BP. Statistical Review of World Energy, BP plc, London, 2013. http://goo.gl IYlNIP (accessed 23.03.15).

[2] The International Energy Agency (IEA). http://www.iea.org.

[3] H. Nakagami, C. Murakoshi, Y. Iwafune, International comparison of household energy consumption and its indicator, ACEEE Summer Study Energy Effic. Build.; Pacific Grove, CA, USA, (2008) 214-224. http://goo.gl/F6Fxjv (accessed 23.03.15)

[4] J. Hakala, Statistics Finland: Energy Consumption in Households 2012, 2012 http://goo.gl/yQqVLe (accessed 23.03.15)

[5] L. Lopes, S. Hokoi, H. Miura, K. Shuhei, Energy Build. 37 (2005) 698-706.

[6] S. Ashina, T. Nakata, Appl. Energy 85 (2008) 101-114.

[7] H. Ren, W. Gao, Energy Build. 42 (2010) 853-861.

[8] H.I. Onovwiona, V.I. Ugursal, Renew. Sustain. Energy Rev. 10 (2006) 389-431.

[9] A.D. Hawkes, I. Staffell, D. Brett, Energy Environ. Sci. 2 (2009) 729-744.

[10] G. McLean, Int. J. Hydrog. Energy 27 (2002) 507-526.

[11] E. Guelzow, J.K. Nor, P.K.N. And, M. Schulze, Fuel Cell Rev. 3 (2006) 3-9.

[12] N. Zuliani, R. Taccani, Appl. Energy 97 (2012) 802-808.

[13] P.E. Dodds, A.D. Hawkes, W. McDowall, F. Li, I. Staffell, P. Grünewald, et al. The Role of Hydrogen and Fuel Cells in Providing Affordable, Secure Lowcarbon Heat, H2FC SUPERGEN, London, 2014. http://goo.gl/hLJORp.

[14] H. Maru, S.C. Singhal, C. Stone, D. Wheeler, 1-10 KW Stationary Combined Heat and Power Systems Status and Technical Potential, National Renewable Energy Laboratory, USA, 2010. http://goo.gl/T6c3C0.

[15] 4th Energy Wave, Fuel Cell Annual Review, 2014. http://tinyurl.com/ pm5qfhw (accessed 5.5.15).

[16] Fuel Cell CHP Passes the Point of No Return, 2014. http://goo.gl/JDylkr (accessed 25.03.15)

[17] R. Rose, J. Gangi, S. Curtin, Fuel Cell Technologies Market Report 2012, Department of Energy, USA, 2013. http://goo.gl/UHIebl.

[18] I. Staffell, R. Green, Int. J. Hydrog. Energy 38 (2013) 1088-1102.

[19] P.E. Dodds, I. Staffell, A.D. Hawkes, F. Li, P. Grünewald, W. McDowall, P. Ekins, Int. J. Hydrog. Energy 40 (2015) 2065-2083.

[20] The fuel cell industry review, Fuel Cell Today, (2013). http://goo.gl/tUjvG9 (accessed 23.03.15).

[21] Country update of Japan, Current status of $\mathrm{H}_{2}$ and fuel cell programs of Japan, in: 20th International Partnership for Hydrogen and Fuel Cells (IPHE) Steering Committee Meeting, 2013. http://goo.gl/AaD2lb (accessed 23.03.15).

[22] S. Curtin and B. Scherer, Residential Scale Power Generation. http://goo.gl/ sl7oRm (accessed 23.03.15).

[23] CHP/DHC Country Scorecard: Germany, International Energy Agency. http:// goo.gl/u0U6Z8 (accessed 23.03.15).

[24] Panasonic and Viessmann to Sell Europe's First Fuel Cell Cogeneration System for Homes, 2013. http://goo.gl/PMnDvO (accessed 23.03.15).

[25] A.H. Pedersen, P. Balslev, Demonstration of micro CHP based on Danish fuel cells, in: The Fuel Cell Seminar and exposition; Arizona, USA, 2008. http:// goo.gl/x6zry1 (accessed 25.03.15).

[26] Danish factsheet, International Energy Agency. http://goo.gl/P4p9D9 (accessed 6.04.14)

[27] Micro-combined Heat and Power is to Replace Oil-Fired Boilers. http://goo gl/Z9a5ix (accessed 25.03.15).

[28] National Organisation Hydrogen and Fuel Cell Technology's Annual Report, National Organization Hydrogen and Fuel Cell Technology' (NOW GmbH) 2012. http://goo.gl/UXgfLZ (accessed 25.03.15)

[29] S. Dwyer, Micro-CHP Japan Continues to Lead as Fuel Cell Units Emerge 2012. http://goo.gl/ZKBb6p (accessed 23.03.15).

[30] J. Harrison, Miro Fuel Cell CHP. http://www.microchap.info (accessed 23.03.15).

[31] S. Eguchi, ENE.FARM Fuel Cell Systems for Residential Use, 2009. http://goo $\mathrm{gl} / \mathrm{yWHK} 5 \mathrm{r}$ (accessed 25.03.15).

[32] Ceres Power Annual Report 2014, Ceres Power Holdings plc, 2014. http:// goo.gl/z9S5g5 (accessed 25.03.15).

[33] Hydrogen and Fuel Cell Global Commercialization and Development Update, International Partnership for Hydrogen and Fuel Cells (IPHE), 2012. http:// goo.gl/dGpz7Y (accessed 25.03.15).

[34] B.G. Pollet, S. Pasupathi, G. Swart, K. Mouton, M. Lototskyy, M. Williams, P. Bujlo, S. Ji, B.J. Bladergroen, V. Linkov, Int. J. Hydrog. Energy 39 (2014) 3577-3596.

[35] S.J. McPhail, L. Leto, C. Boigues-Muñoz, The Yellow Pages of SOFC Technology, International Status of SOFC Deployment 2012-2013, 2013. http://goo.gl NcHehu (accessed 25.03.15).
[36] H. Johnstone, BlueGEN Micro-CHP to Target Fuel Poverty in UK, 2013. http:// goo.gl/JbZqU8 (accessed 23.03.15)

[37] Delta-EE, CFCL Enters Administration, 2015. http://tinyurl.com/lnl8odw (accessed 5.5.15)

[38] World Energy Outlook (WEO). http://www.worldenergyoutlook.org .

[39] Callux, Practical Tests for Fuel Cells in a Domestic Setting. www.callux.net/ home.English.html.

[40] K. Föger, CFCL: challenges in commercialising an ultra-efficient SOFC residential generator, in: International Partnership for Hydrogen and Fuel Cells (IPHE) Workshop on Stationary Fuel Cells, Tokyo, 2011. http://tinyurl.com/ 82eqw7h (accessed 25.03.15).

[41] Statistical Data Set: Annual Domestic Energy Bills, 2014. UK, http://tinyurl. com/o8zybas (accessed 23.03.15)

[42] K. Brooks, S. Pilli, A. Makhmalbaf, V. Srivastava, D. Anderson, J. Upton, et al., Business Case for a Micro-combined Heat and Power Fuel-cell System in Commercial Applications, Pacific Northwest National Laboratory, USA, 2013. http://goo.gl/b2xX1T.

[43] I. Staffell, The Energy and Fuel Data Sheet, 2011. http://goo.gl/hvByt9.

[44] A.D. Hawkes, Energy Policy 38 (2010) 5977-5987.

[45] I. Staffell, Appl. Energy 147 (2015) 373-385.

[46] ClearEdge Power, Purecell Model 400 Fuel Cell System Datasheet, 2014. http://goo.gl/HZ2XHS (accessed 23.03.15).

[47] FuelCell Energy, DFC300 Datasheet, 2013. http://tinyurl.com/oh9pl9j (accessed 23.03.15).

[48] I. Staffell, A. Ingram, K. Kendall, Int. J. Hydrog. Energy 37 (2012) 2509-2523.

[49] I. Staffell, A. Ingram, Int. J. Hydrog. Energy 35 (2010) 2491-2505.

[50] W. Moomaw, P. Burgherr, G. Heath, M. Lenzen, J. Nyboer, A. Verbruggen, Annex II: methodology, in: O. Edenhofer, R. Pichs-Madruga, Y. Sokona, K. Seyboth, P. Matschoss, S. Kadner, et al. (Eds.), IPCC Special Report on Renewable Energy Sources and Climate Change Mitigation, Cambridge University Press, Cambridge, 2011.

[51] Carbon Footprint of Electricity Generation, 2011. London, http://goo.gl/ NwURez.

[52] Pollutant Information: Sulphur dioxide. http://www.epa.gov/air/ sulfurdioxide (accessed 23.03.15).

[53] Review of Combined Heat and Power Technologies, Department of Energy (DOE), USA, 1999. http://goo.gl/hnCNXI (accessed 23.03.15).

[54] I. Staffell, P. Baker, J. Barton, N. Bergman, R. Blanchard, N. Brandon, et al., UK microgeneration. Part II: the technologies, Proc. ICE Energy (2010) 143-165.

[55] I. Staffell, Fuel Cells for Domestic Heat and Power: Are they Worth it? University of Birmingham, 2009. http://goo.gl/JB4Yjp.

[56] European Energy Price Statistics. http://ec.europa.eu/eurostat (accessed 25.03.15).

[57] D.L. Greene, K.G. Duleep, G. Upreti, Status and Outlook for the U.S. Nonautomotive Fuel Cell Industry: Impacts of Government Policies and Assessment of Future Opportunities, 2011. http://goo.gl/bIA7GV (accessed 25.03.15).

[58] Electric Power Transmission and Distribution Losses, 2011. http://data. worldbank.org/indicator/EG.ELC.LOSS.KH (accessed 23.03.15).

[59] A. Chen, Berkeley Lab Study Estimates \$80 Billion Annual Cost of Power Interruption, Berkeley lab, USA, 2005. http://goo.gl/tRVT9F (accessed 23.03.15).

[60] T. Patterson, U.S. Electricity Blackouts Skyrocketing, 2010. http://goo.gl/ M7vcc2 (accessed 23.03.15).

[61] J. Wing, Handling the cost of residential fuel cells, Fuel Cell Today (2013). http://goo.gl/Py0JN4.

[62] I. Staffell, R.J. Green, Int. J. Hydrog. Energy 34 (2009) 5617-5628.

[63] T. Shimizu, Panasonic's Latest Technology Trend in ENE-farm and Penetration Strategy, FC-EXPO, Tokyo, 2013.

[64] Launch of New "Ene-farm" Home Fuel Cell Product More Affordable and Easier to Install, 2013. http://goo.gl/A9ze9m (accessed 23.03.15).

[65] K. Alanne, A. Saari, V.I. Ugursal, J. Godat, J. Power Sources 158 (2006) 403-416.

[66] I. Staffell, R. Green, K. Kendall, J. Power Sources 181 (2008) 339-349.

[67] M.Y. El-Sharkh, A. Rahman, M.S. Alam, J. Power Sources 139 (2005) 165-169.

[68] M.Y. El-Sharkh, M. Tanrioven, A. Rahman, M.S. Alam, J. Power Sources 161 (2006) 1198-1207.

[69] A.D. Hawkes, P. Aguiar, C.A. Hernandez-Aramburo, M.A. Leach, N.P. Brandon, T.C. Green, et al., J. Power Sources 156 (2006) 321-333.

[70] A.D. Hawkes, M.A. Leach, Energy 32 (2007) 711-723.

[71] A. Ferguson, V. Ismet Ugursal, J. Power Sources 137 (2004) 30-42.

[72] F. Marechal, F. Palazzi, J. Godat, D. Favrat, Fuel Cells 5 (2005) 5-24.

[73] F. Palazzi, N. Autissier, F.M.A. Marechal, D. Favrat, Appl. Therm. Eng. 27 (2007) 2703-2712.

[74] C. Wallmark, P. Alvfors, J. Power Sources 106 (2002) 83-92.

[75] J. Godat, F. Marechal, J. Power Sources 118 (2003) 411-423.

[76] M. Beedie, GE's H-series Breaks 60\% Fuel Efficiency Barrier, 2007. http:// tinyurl.com/yl7qlcd (accessed 23.03.15).

[77] I. MacLeay, K. Harris, C. Michaels, Chapter 5: electricity, in: Digest of UK Energy Statistics, National Statistics, UK, 2014. http://goo.gl/HKzcln.

[78] International energy agency, World Energy Balances, 2012, 2012. http://dx. doi.org/10.5257/iea/web/2012.

[79] K. Kuwaba, Development of SOFC for Residential Use by Aisin Seiki, FC Expo, Tokyo, 2013.

[80] H. Maru, S.C. Singhal, C. Stone, D. Wheeler, 1 - 10 KW Stationary Combined 
Heat and Power Systems Status and Technical Potential, National Renewable Energy Laboratory, USA, 2010. http://www.hydrogen.energy.gov/pdfs/ 48265.pdf.

[81] Y. Nagata, Toshiba Fuel Cell Power Systems: Commercialization of Residential FC in Japan, FCH-JU General Assembly, Brussels, Japan, 2013. http:// tinyurl.com/q8ov9td.

[82] J. Spendelow, J. Marcinkoski, D. Papageorgopoulos, Micro CHP Fuel Cell System Targets, Department of Energy (DOE), USA, 2012. http://goo.gl/ fqDvZ1.

[83] S.-D. Oh, K.-Y. Kim, S.-B. Oh, H.-Y. Kwak, Appl. Energy 95 (2012) 93-101.

[84] S.J. Andreasen, S.K. Kær, Int. J. Hydrog. Energy 33 (2008) 4655-4664.

[85] S.J. Andreasen, L. Ashworth, I.N.M. Remon, P.L. Rasmussen, M.P. Nielsen, ECS Trans. 12 (2008) 639-650.

[86] UTC Power, Energy Reinvented: Stationary Fuel Cells, Hanover Messe, 2012. http://goo.gl/iImyAA.

[87] M. Miller, A. Bazylak, J. Power Sources 196 (2011) 601-613.

[88] S. Iwata, Status of Residential SOFC Development at Osaka Gas, FC EXPO, Tokyo, 2014.

[89] R. Knibbe, A. Hauch, J. Hjelm, S.D. Ebbesen, M. Mogensen, Green 1 (2011) $127-240$.

[90] L.G.J. de Haart, SOFC-life, FCH-JU Programme Review Day, Brussels, 2012. http://goo.gl/PSJ7vZ.

[91] H. Yokokawa, T. Horita, K. Yamaji, H. Kishimoto, M.E. Brito, J. Korean Ceram. Soc. 49 (2012) 11-18.

[92] A.D. Hawkes, D.J.L. Brett, N.P. Brandon, Int. J. Hydrog. Energy 34 (2009) 9558-9569.

[93] A. Chandan, M. Hattenberger, A. El-kharouf, S. Du, A. Dhir, V. Self, et al., J. Power Sources 231 (2013) 264-278.

[94] J.O. Jensen, Q. Li, C. Pan, N.J. Bjerrum, H.C. Rudbeck, T. Steenberg, Ongoing efforts addressing degradation of high temperature PEMFC, in: World Hydrog. Energy Conference, Germany, 2010.

[95] Z.Q. Qi, C.Z. He, A. Kaufman, J. Power Sources 111 (2002) 239-247.

[96] J. Zhang, Z. Xie, J. Zhang, Y. Tang, C. Song, T. Navessin, et al., J. Power Sources 160 (2006) 872-891.

[97] P. Bujlo, S. Pasupathi, J. Scholta Ulleberg, M.V. Nomnqa, A. Rabiu, et al., Int. J. Hydrog. Energy 38 (2013) 9847-9855.

[98] B.D. James, A.B. Spisak, Mass Production Cost Estimation of Direct H2 PEM Fuel Cell Systems for Transportation Applications, 2012. http://goo.gl/4LRzui.

[99] Y. Sun, M. Delucchi, J. Ogden, Int. J. Hydrog. Energy 36 (2011) 11116-11127.

[100] B.D.R. Wilburn, D.I. Bleiwas, Platinum-group Metals-World Supply and Demand, 2004. http://pubs.usgs.gov/of/2004/1224/2004-1224.pdf.

[101] A. Cowley, Platinum 2013 Interim Review, 2013. http://goo.gl/HDTfbQ.

[102] B.J. Glaister, G.M. Mudd, Min. Eng. 23 (2010) 438-450.

[103] A. Elshkaki, Resour. Policy 38 (2013) 241-251.
[104] Hydrogen Production and Distribution, 2007. http://goo.gl/U7R2Yz.

[105] C. Song, Catal. Today 77 (2002) 17-49.

[106] K. Ledjeff-Hey, T. Kalk, F. Mahlendorf, O. Niemzig, A. Trautmann, J. Roes, J. Power Sources 86 (2000) 166-172.

[107] Y.-S. Seo, A. Shirley, S.T. Kolaczkowski, J. Power Sources 108 (2002) 213-225.

[108] T. Giroux, S. Hwang, Y. Liu, W. Ruettinger, L. Shore, Appl. Catal. B Environ. 56 (2005) 95-110.

[109] R.R. W, J.E. Cuzens, Autothermal Reforming of Natural Gas: a Key Technology for Fuel Cells, International Gas Research Conference, Amsterdam, 2001.

[110] A. Ersoz, H. Olgun, S. Ozdogan, J. Power Sources 154 (2006) 67-73.

[111] C.-E. Hubert, P. Achard, R. Metkemeijer, J. Power Sources 156 (2006) 64-70.

[112] I. Yasuda, T. Miura, H. Fujiki, J. Komiya, Y. Shirasaki, T. Seki, Development of Highly-efficient and Compact Fuel Processors for PEFC Applications, International Gas Research Conference, Amsterdam, 2001.

[113] J.K. Lampert, Y. Liu, W. Ruettinger, S. Hwang, R.J. Farrauto, X. Liu, et al., Fue Cell Seminar Proceedings, 2003, pp. 914-917. Florida, USA.

[114] R.J. Farrauto, Y. Liu, W. Ruettinger, O. Ilinich, L. Shore, T. Giroux, Catal. Rev. 49 (2007) 141-196.

[115] D.S. Schmidt, Status of the Acumentrics SOFC Program, Fuel Cell Seminar and Exposition, Honolulu, 2006.

[116] L. Salemme, L. Menna, M. Simeone, Energy 57 (2013) 368-374.

[117] T. Semelsberger, Int. J. Hydrog. Energy 29 (2004) 1047-1064.

[118] D.J.L. Brett, M. Manage, E. Agante, N.P. Brandon, E. Brightman, R.J.C. Brown, et al., Fuels and fuel processing for low temperature fuel cells, in: C. Hartnig C. Roth (Eds.), Polymer Electrolyte Membrane and Direct Methanol Fuel Cell Technology, Fundam. Perform. Low Temp. Fuel Cells, vol. 1, Woodhead Publishing, Cambridge, 2012.

[119] Q. Li, R. He, J.-A. Gao, J.O. Jensen, N.J. Bjerrum, J. Electrochem. Soc. 150 (2003) A1599.

[120] S.J. Andreasen, J.R. Vang, S.K. Kær, Int. J. Hydrog. Energy 36 (2011) 9815-9830.

[121] A. Faghri, Z. Guo, Int. J. Heat Mass Transf. 48 (2005) 3891-3920.

[122] S.G. Kandlikar, Z. Lu, Appl. Therm. Eng. 29 (2009) 1276-1280.

[123] J. Scholta, M. Messerschmidt, L. Jörissen, C. Hartnig, J. Power Sources 190 (2009) 83-85.

[124] T.-W. Song, K.-H. Choi, J.-R. Kim, J.S. Yi, J. Power Sources 196 (2011) 4671-4679.

[125] G. Zhang, S.G. Kandlikar, Int. J. Hydrog. Energy 37 (2012) 2412-2429.

[126] J. Supra, H. Janßen, W. Lehnert, D. Stolten, Int. J. Hydrog. Energy 38 (2013) 1943-1951.

[127] E.H. Reddy, D.S. Monder, S. Jayanti, Appl. Therm. Eng. 58 (2013) 155-164.

[128] B.D. James, A.B. Spisak, W.G. Colella, Manufacturing Cost Analysis of Stationary Fuel Cell Systems, 2012. Arlington, http://goo.gl/CR2d80. 